\title{
"LEST YOU UNDERMINE OUR STRUGGLE": SYMPATHETIC ACTION AND THE CANADIAN CHARTER OF RIGHTS AND FREEDOMS
}

\begin{abstract}
KeIR J.M. VALLANCE*
In this new era of recognized constitutional labour rights, one aspect of labour relations sympathetic action - remains, for the most part, judicially unexamined. This article examines the case law to demonstrate that there is a constitutional argument that both the statutory prohibition on sympathetic action, and the hostility to sympathetic action in the common law of contract and tort, infringe on the freedoms in section 2 of the Charter. However, there is no necessary connection between a right to undertake sympathetic action and a right to strike, nor is freedom of association the only Charter right that can protect sympathetic action. Ultimately, an absolute ban on sympathetic action under Canadian labour law violates the Charter and must be removed; and the hostility of the law of tort and the law of contract to sympathetic action also contravenes Charter values.
\end{abstract}

\section{TABLE OF CONTENTS}

I. INTRODUCTION ............................... 140

II. SyMPATHETIC ACTION IN CANADA: A REVIEW . . . . . . . . . . . . . . 143

III. SyMPATHETIC ACTION: A REVIEW OF EXCEPTIONS .............. 146

IV. SeCtion 2 Of THE CHARTER ....................... 148

A. FREedom of CONSCIENCE AND SyMPATHETIC ACTION $\ldots \ldots \ldots 151$

B. FREEDOM OF CONSCIENCE, THE LAW OF CONTRACT, AND THE LAW OF TORT $\ldots \ldots \ldots \ldots \ldots \ldots \ldots \ldots \ldots \ldots \ldots$

C. FREEDOM OF CONSCIENCE IN HUMAN RightS LEGISLATION . . . . . 159

D. FREEDOM OF EXPRESSION AND SYMPATHETIC ACTION ......... 160

E. FREEDOM OF ASSOCIATION AND SYMPATHETIC ACTION ......... 164

F. Freedom of AsSociation AND the Peace Obligation ....... 166

G. FrEedom of ASSOCIATION, THE LAW OF CONTRACT, AND THE LAW OF TORT $\ldots \ldots \ldots \ldots \ldots \ldots \ldots \ldots \ldots \ldots$

V. Sympathetic Action AND SeCtion 1:

Limits Justifiable In A FreE AND DEMOCRATIC SOCIETY . . . . . . . . 167

A. Pressing and Substantial ObJective $\ldots \ldots \ldots \ldots \ldots . \ldots 167$

B. Proportionality: Rational CONNECTION $\ldots \ldots \ldots \ldots \ldots 168$

C. Proportionality: Minimal IMPAIRMENT $\ldots \ldots \ldots \ldots \ldots \ldots .168$

D. PRoportionality: Detrimental vs. SAlutary EFFECTS . . . . . 169

Assistant Professor, College of Law, University of Saskatchewan. This article is derived from a portion of my Master's thesis and I am indebted to my supervisor, Professor Beth Bilson, and my committee members, Ken Norman and Mark Carter, all of the College of Law, University of Saskatchewan, and Professor Charles Smith of St Thomas More College, Saskatoon, Saskatchewan, for their helpful comments and guidance during the thesis drafting and defence process. Professor Sarah Burningham of the College of Law, University of Saskatchewan, also provided indispensable insight and advice. My thanks also to my anonymous peer reviewers, who provided valuable and much-appreciated comments and feedback. I must also, albeit sadly, express my gratitude to the late Professor Geoffrey England of the Edwards School of Business for his enthusiasm and assistance during the early stages of my thesis - thanks, mate. Any errors or omissions in this article are, of course, entirely my own doing. 
VI. Moving Forward: SUGgestions FOR REFORM . . . . . . . . . . . 170

A. STATUTORY REFORM . . . . . . . . . . . . . . . . . . . . . . . . . 170

B. THE COMMON LAW: TORT AND CONTRACT . . . . . . . . . . 172

VII. CONCLUSION ............................ 174

One of the great strengths of the trade union movement is the spirit of solidarity. By standing together as a collective whole, trade unionists are able to aspire to improved wages and working conditions unattainable if each individual member were left to his or her own devices. Solidarity is made manifest when one group of workers is on strike. Fellow unionists and other sympathetic members of the public are made aware of the strike by the presence of picketers. Picketing sends a strong and automatic signal: do not cross the line lest you undermine our struggle. ${ }^{1}$

Chief Justice Brian Dickson

This Government had an idea, and Parliament made it law.

Seems like it's illegal to fight for the Union any more.

So which side are you on, boys? Which side are you on?

Which side are you on, boys? Which side are you on? ${ }^{2}$

\section{Billy Bragg}

\section{INTRODUCTION}

Two recent decisions from the Supreme Court of Canada - Mounted Police Association of Ontario v. Canada (Attorney General) ${ }^{3}$ and Saskatchewan Federation of Labour v. Saskatchewan ${ }^{4}$ — have well and truly granted "constitutional benediction" 5 under the Canadian Charter of Rights and Freedoms ${ }^{6}$ to the right to belong to an independent trade union $^{7}$ and to the right to strike. ${ }^{8}$ Both cases built upon the ground-breaking 2007 BC Health Services decision, ${ }^{9}$ which granted similar benediction to the right to collective bargaining. However, even in this new era of recognized constitutional labour rights, one aspect of labour relations - sympathetic action — remains, for the most part, judicially unexamined..$^{10}$

BCGEU v British Columbia (Attorney General), [1988] 2 SCR 214 at 231 [BCGEU].

"Which Side are you On," Vinyl: Back to Basics (London: Cooking Vinyl, 1987).

2015 SCC 1, [2015] 1 SCR 3 [MPAO].

2015 SCC 4, [2015] 1 SCR 245 [SFL].

Ibid at para 3 .

Part I of the Constitution Act, 1982, being Schedule B to the Canada Act 1982 (UK), 1982, c 11

[Charter].

MPAO, supra note 3.

SFL, supra note 4.

Health Services and Support - Facilities Subsector Bargaining Assn v British Columbia, 2007 SCC 27, [2007] 2 SCR 391 [BC Health Services].

10 The Court in SFL, supra note 4, notes that "[t]he question of whether other forms of collective work stoppage are protected by s. $2(d)$ of the Charter is not at issue here" at para 2 . I should note that this article was originally written prior to the release of MPAO and SFL. The arguments herein were (and are) therefore not reliant upon the recognition of a constitutional right to strike. The new Supreme Court labour jurisprudence, however, has undeniable repercussions to any constitutional argument in this area - particularly regarding freedom of association. 
Sympathetic action is, at its most basic, "by one group of workers designed to help another group that is involved in a strike or lockout." ${ }^{11}$ It is a broad term that manifests in many ways. It can include, inter alia, workers refusing to cross a picket line or "locked gate"; refusing to handle goods from a struck workplace; or refusing to enable their own employer to increase production to make up for shortfalls due to another workplace being struck. It is an expression of solidarity among workers, and is a key plank in the foundation upon which organized labour's early successes were built.

However, with some notable exceptions, sympathetic action is almost always treated with hostility by Canadian law. Sympathetic action, when taken collectively, generally qualifies as an illegal "strike." Unions and workers who engage in sympathetic action can face injunctions, fines, or sanctions under labour relations legislation, as they can with any illegal strike. ${ }^{13}$ Individual workers are vulnerable to discipline or dismissal for breach of contract. Both unions and workers may be vulnerable to being sued for damages pursuant to the socalled "industrial torts." 14

In the one upper court case to consider sympathetic action post-BC Health Services, the Federal Court of Appeal in Grain Workers held that there is no right to strike and therefore necessarily no right to sympathetic action. ${ }^{15}$ Relying upon the "Labour Trilogy," judges accepted that freedom of association under section 2(d) of the Charter did not protect a right to strike and therefore would not apply to sympathetic action either. ${ }^{17}$ On the face of it, this aspect of the reasons in Grain Workers clearly can no longer stand given that as the Supreme Court in SFL has now recognized a right to strike as an "essential component" of collective bargaining and worthy of constitutional protection. ${ }^{18}$ Of course it also does not necessarily follow that recognition of a constitutional right to strike must lead to recognition of a constitutional right to undertake sympathetic action.

The majority in Grain Workers (Justice Evans dissented on this point) also held that refusing to cross a picket line was an intrusion into a private contractual dispute. As such, this was not a protected form of expression and the Charter's section 2(b) did not apply. ${ }^{19}$ Needless to say, and with respect, I believe that the Grain Workers decision was wrongly decided then, and is certainly unsupportable now. I contend that case law from Dunmore ${ }^{20}$

11 Labour Law Casebook Group, Labour and Employment Law: Cases, Materials, and Commentary, 6th ed (Kingston: Irwin Law, 2004) at 452.

12 International Longshoremen's Association v Maritime Employers' Association, [1979] 1 SCR 120 [International Longshoremen]; Grain Workers' Union, Local 333 v BC Terminal Elevator Operators' Assn, 2009 FCA 201, [2010] 3 FCR 255 [Grain Workers], leave to appeal to SCC refused, 33322 (17 December 2009). A union can even face penalties for not taking an active role, or not an active enough role, in preventing
or ending an illegal strike: see e.g. Re Westroc Industries Ltd and CAW, Local 1256 (Hubbert) (2001), 2001 CarswellOnt 10093 (Ont LRB).

14 See e.g. HW Arthurs, "Tort Liability for Strikes in Canada: Some Problems of Judicial Workmanship" (1960) 38:3 Can Bar Rev 346.

Supra note 12.

The "Labour Trilogy" is defined by the Court in Grain Workers (ibid at para 23) as a series of three Supreme Court cases: Reference re Public Service Employee Relations Act (Alta), [1987] 1 SCR 313; PSAC v Canada, [1987] 1 SCR 424; and RWDSU v Saskatchewan, [1987] 1 SCR 460.

17 Grain Workers, ibid at para 91 (Blais JA); ibid at para 96 (Ryer JA). Justice Evans, in his reasons, was not as categorical in this regard as Justices Blais and Ryer but nonetheless held that section 2(d) did not apply in the case before him (ibid at paras 23-24).

SFL, supra note 4 at para 46.

Supra note 12 at paras 88-90, Blais JA; para 96, Ryer JA.

Dunmore v Ontario (Attorney General), 2001 SCC 94, [2001] 3 SCR 1016 [Dunmore]. 
through BC Health Services and, now, MPAO and SFL, provide the basis for a constitutional argument that both the statutory prohibition on sympathetic action, and the hostility to sympathetic action of the common law of contract and tort, infringe the freedoms in section 2 of the Charter. However, I also contend that there is no necessary connection between a right to undertake sympathetic action and a right to strike, nor is freedom of association the only Charter freedom that could protect sympathetic action. I base this argument on three main points.

First, the so-called "peace obligation" 21 - the statutory ban on strike activity by workers or their union (as well as a bar on lockouts by their employer ${ }^{22}$ ) during the term of a collective agreement - invariably renders the collective exercise of sympathetic action untimely and therefore prohibited. This prohibition offends freedom of association under section 2(d) of the Charter outright because it prohibits associational activity as such; and because the prohibition is statutory, the Charter may be applied directly. Because the prohibition during the term of a collective agreement is absolute, I argue, it cannot be saved under section 1 .

Second, the exercise of sympathetic action can be conscientious, which potentially triggers freedom of conscience under section 2(a) of the Charter. The peace obligation does not technically prohibit a conscientious refusal to cross a picket line, for instance (since only collective sympathetic action is prohibited). However, I argue that the peace obligation infringes upon freedom of conscience because workers who undertake sympathetic action individually are very vulnerable to employer retaliation — so the peace obligation renders impotent a worker's freedom of conscience. Furthermore, for dedicated trade unionists, conscience may dictate an associational response to a strike or picket line. Finally, I contend that the conscientious content of sympathetic action renders collective sympathetic action closer to the core of values protected by the Charter and as such strengthens a claim of infringement under section 2(d) in addition to an inherent infringement of section 2(a) itself.

In addition to challenging the peace obligation, I argue also mandating a relaxation or elimination of the common law penalties relating to sympathetic action. While the Charter does not apply directly to relationships between private parties ${ }^{23}$ or in the absence of state action, ${ }^{24}$ the common law (in this case tort and contract) must adapt to conform to Charter values. ${ }^{25}$ Therefore, the common law penalties should be relaxed or eliminated to reflect protection of sympathetic action under section 2(a). an employer's ability to lock out, or to unilaterally change terms and conditions of employment, are undeniably important (especially when undertaken in response to strike action or to roll back terms and conditions of employment), in general the countervailing power of the employer is not the lockout, but its right to manage the workplace and its ability to "take a strike," rather than its right to lock out its workers: see Geoffrey England, "Some Thoughts on Constitutionalizing the Right to Strike" (1988) 13:2 Queen's LJ 168 at 177 [England, "Right to Strike"].

RWDSU v Dolphin Delivery Ltd, [1986] 2 SCR 573 [Dolphin Delivery].

Hill $v$ Church of Scientology of Toronto, [1995] 2 SCR 1130 at para 91 [Hill].

Ibid at para 95. 
Third, while not all sympathetic action may be taken on conscientious grounds, the exercise of sympathetic action is inevitably expressive. That potentially triggers freedom of expression under section 2(b) of the Charter. My arguments regarding infringement of 2(b) are very much the same as those under 2(a).

While I deal primarily with the Charter in this article, it is also worth noting that three Canadian jurisdictions - Saskatchewan, Quebec, and the Yukon Territory — have included fundamental freedoms similar to those found within section 2 of the Charter within their provincial legislation. ${ }^{26}$ It would seem undeniable that similar arguments for protection of sympathetic action may be made under these provincial statutes and that these statutes, unlike the Charter, may apply directly to private action. When dealing with the common law, therefore, I will also consider the potential impact of provincial legislation.

\section{SyMPathetic ACTION In CANADA: A REVIEW}

The vast majority of Canadian employees operate under the common law of employment. ${ }^{27}$ However under both the common law and collective bargaining regimes as they currently stand, sympathetic action is almost always illegal. While restrictions on strikes over the past century-and-a-half were gradually relaxed ${ }^{28}$ (admittedly with an increase in restrictions on strike activity since the $1980 \mathrm{~s})^{29}$ sympathetic action has been illegal in most Canadian jurisdictions and remains so today. The peace obligation is present in every Canadian labour relations statute. ${ }^{30}$

Among the industrialized market economies, Canadian restrictions on industrial action are among the most expansive. ${ }^{31}$ At common law, any job action short of actual stoppage of work is likely not a strike, ${ }^{32}$ but the modern Canadian labour relations regime will view almost any sympathetic action, if taken collectively, as a strike. ${ }^{33}$ This can apply to collective action

The Saskatchewan Human Rights Code, SS 1979, c S-24.1, ss 4-8; Charter of Human Rights and Freedoms, CQLR c C-12, ss 1-9.1 [Quebec Charter]. Human Rights Act, RSY 2002, c 116, ss 3-6.

Statistics Canada, "Unionization 2011," by Sharanjit Uppal, in Perspectives on Labour and Income, vol 23 No 4, Catalogue No 75-001-X (Ottawa: Statistics Canada, 26 October 2011), online: <www.statcan. gc.ca/pub/75-001-x/2011004/article/11579-eng.pdf> (in 2011, 30 percent of Canadian workers were unionized. However, while three in four public sector workers were unionized, over four in five private sector workers were not).

For a summary of the evolution of strike regulation in Canada, see Judy Fudge \& Eric Tucker, "The Freedom to Strike in Canada: A Brief Legal History" (2010) 15:2 CLELJ 333.

29 See e.g. Leo Panitch \& Donald Swartz, From Consent to Coercion: The Assault on Trade Union Freedoms (Aurora: Garamond Press, 2003) (where the increase in back-to-work legislation is characterized as "permanent exceptionalism" at 25) at 54; Charlotte AB Yates, "In Defence of the Right to Strike" (2009) 59:1 UNBLJ 128.

30 Labour Relations Code, RSBC 1996, c 244, s 57 [BC Labour Relations Code]; Labour Relations Code, RSA 2000, c L-1, ss 71-74 [AB Labour Relations Code]; The Saskatchewan Employment Act, SS 2013, c S-15.1, s 6-30; Labour Relations Act, CCSM c L10, ss 89, 91 [MB Labour Relations Act]; Labour Relations Act, 1995, SO 1995, c 1, s 79 [ON Labour Relations Act]; Labour Code, RSQ c C-27, ss 107-108; Industrial Relations Act, RSNB 1973, c I-4, s 53; Trade Union Act, RSNS 1989, c 475, s 47; Labour Act, RSPEI 1988, c L-1, s 36; Labour Relations Act, RSNL 1990, c L-1, s 99 [NL Labour Relations Act]; Canada Labour Code, RSC 1985, c L-2, s 88.1.

31 ATJM Jacobs, "The Law of Strikes and Lockouts" in R Blanpain, ed, Comparative Labour Law and Industrial Relations in Industrialized Market Economies, 8th ed (The Hague: Kluwer Law International, 2004) 549 at 560-61.

32 See e.g. Richard Hyman, Strikes, 2nd ed (London: Fontana, 1977) at 17; Otto Kahn-Freund, Labour and the Law, 2nd ed (London: Stevens \& Sons, 1977) at 227; Otto Kahn-Freund \& Bob Hepple, Laws Against Strikes, (London: Fabian Society, 1972) at 4; UKHC, "Royal Commission on Trade Unions and Employers' Associations," Cmnd 3623 in Sessional Papers, vol 32 (1967-68) at 242 [Donovan Report]. 33 George W Adams, Canadian Labour Law, 2nd ed (Aurora: Canada Law Book, 1993) (loose-leaf updated 2015, release 55), vol 2 ch 11 at 2-6.1. 
whether taken by workers certified under the relevant labour relations legislation or not. ${ }^{34}$ Of course, unionized workers engaged in a legal strike receive a number of statutory protections that non-unionized workers do not. ${ }^{35}$

The definition of a "strike" in the Canada Labour Code is representative of Canadian labour legislation:

\begin{abstract}
"Strike" includes a cessation of work or a refusal to work or to continue to work by employees, in combination, in concert or in accordance with a common understanding, and a slowdown of work or other concerted activity on the part of employees in relation to their work that is designed to restrict or limit output. $^{36}$
\end{abstract}

Such a broad definition has been described as "objective" 37 or "effects based"38 in that the purpose of the activity is not relevant, only that it be done collectively ("in combination, in concert or in accordance with a common understanding") and that it limit production (“designed to restrict and limit output").

Six provinces have statutory language similar to that in the Canada Labour Code. ${ }^{39}$ Quebec differs in that its strike definition refers to a "cessation" of work rather than to the broader "restriction of production" definition, but it is similar in that the motivation for the strike is irrelevant. ${ }^{40}$

Alberta, ${ }^{41}$ Manitoba, ${ }^{42}$ and Nova Scotia ${ }^{43}$ differ from the Canadian norm in that they have a subjective element in their statutory language — in that to be considered a "strike," industrial action must have the purpose of compelling an employer to agree to terms and conditions of employment. The purpose component, however, does not bar sympathetic action from being a strike. ${ }^{44}$ Of these three provinces, the courts in Nova Scotia have

Labour Law Casebook Group, supra note 11 at 472.

See e.g. The Saskatchewan Employment Act, supra note 30, ss 6-36-6-37 (protection from employer retaliation); Trade Union Act, supra note 30, s 53(3)(a) (protection from employer retaliation); ON Labour Relations Act, supra note 30, s 80 (ability of striking workers to return to their jobs after conclusion of the strike).

Supra note 30, s 3(1).

Brian Langille, "What Is a Strike?" (2010) 15:2 CLELJ 355; England, "Peace Obligation," supra note 21 at 537.

BCTF v British Columbia Public School Employers’ Assn, 2009 BCCA 39, 306 DLR (4th) 144 at para 3, leave to appeal to SCC refused, 33112 (20 August 2009) [BCTF].

While the actual wording differs, the provisions are similar enough (insofar as they have no subjective element) that they are not reproduced here. See e.g. BC Labour Relations Code, supra note 30, s 1(1); The Saskatchewan Employment Act, supra note 30, s 6-1(1)(n); ON Labour Relations Act, supra note 30, s 1; Industrial Relations Act, supra note 30, s 2; Labour Act, supra note 30, s 7(1)(1); NL Labour Relations Act, supra note 30, s 2(1)(v).

Labour Code, supra note 30, s 1 (g). However the Labour Code includes a restriction on other, lesser forms of industrial action as well - just not within the definition of "strike" (at s 108).

AB Labour Relations Code, supra note 30, s 1(v).

MB Labour Relations Act, supra note 30, s 1.

Trade Union Act, supra note 30, s 2(1)(v).

Note also that even the "objective" strike definition may have an inherently subjective component. For instance, while McKeigan CJA noted in Re Robb Engineering and United Steelworkers of America Local 4122 (1978), 86 DLR (3d) 307 (NSCA) [Robb Engineering] that "[f]our men deciding to go fishing together would not be striking" (at 316), Brian Langille has argued that "on an objective definition, it would have to be a strike. Therefore, we do not have an objective definition" and that "there are many concerted cessations [of work] which are not strikes" (supra note 36 at 359 [footnotes omitted]). 
interpreted the definition of "strike" as inclusive, not exhaustive, and have therefore applied an effects-based interpretation. ${ }^{45}$

Manitoba and Alberta do not appear to have interpreted their strike definitions in the same way as has Nova Scotia. In those two provinces, therefore, a purposive definition seems to still govern. However, the Alberta Board has held that refusing to cross a picket line is, prima facie, an attempt to compel an employer to agree to the strikers' demands: solidarity, said the Board, is not blind to the realities of industrial relations. ${ }^{46}$ Therefore under the Alberta statute, while industrial action generally may have a purpose requirement, it seems that in cases of sympathetic action the Board will infer the purpose necessary to find that the action is an illegal strike.

Therefore sympathetic action, including refusals to cross another union's picket line, ${ }^{47}$ boycotts and (in most, but not all, cases) refusal to handle "hot cargo" from struck employers, ${ }^{48}$ and of course "true" strikes, in sympathy of other unions are all subject to the peace obligation. The one exception may be a refusal of overtime (for instance, to prevent an increase in production intended to make up for loss of production at a struck work site), which would seem to be protected to a certain extent under labour standards legislation in some jurisdictions. ${ }^{49}$ Even where such provisions exist, however, a concerted refusal by workers to work overtime has been held to be a "strike" federally, ${ }^{50}$ and in Ontario ${ }^{51}$ and Saskatchewan, ${ }^{52}$ but not in British Columbia. ${ }^{53}$

Above and beyond the statutory penalties available, workers - unionized or nonunionized, individually or collectively - who refuse to cross a picket line, to handle goods from a struck workplace, or otherwise refuse work in solidarity with striking workers, can face discipline for insubordination. ${ }^{54}$ Furthermore, a strike or sympathetic action may

Robb Engineering, ibid.

McGavin Foods Ltd v RWDSU, Local 980 (1988), 1 CLRBR (2d) 264 at 289-90 (Alta) [McGavin Foods]. See also Re Combustion Engineering Canada Inc, [1987] Alta LRBR 443.

Grain Workers, supra note 12; International Longshoremen, supra note 12. However, individual refusals to cross a picket line may not constitute a "strike": see e.g. Unilux Boiler Corp v USWA, Local 3950 (2005), 118 CLRBR (2d) 108 (Ont).

See e.g. The Kingston Whig-Standard and Communication Workers of America, Loc 204, Re (1995), 51 LAC (4th) 137 [Kingston Whig-Standard], in which a "hot cargo clause" in a collective agreement was found to be contrary to the ban on mid-contract strikes in the Ontario Labour Relations Act (at 138). The right to refuse overtime beyond a certain number of hours per week is set out in some labour standards legislation. See e.g. The Saskatchewan Employment Act, supra note 30, ss 2-12(1); Canada Labour Code, supra note 30, s 171. Manitoba sets out that the employer does not have an implied right to require an employee to work overtime: see The Employment Standards Code, CCSM c E-110, s 19(1). British Columbia only sets out that an employee cannot be required or allowed "to work excessive hours or hours detrimental to the employee's health or safety": see The Employment Standards Act, RSBC 1996, c 113 , s 39.

Re CF Cable TV Inc, 69 di 132 (CLRB); BC Terminal Elevator Operators' Ass'n and Grain Workers' Union, Local 333 (1994), 23 CLRBR (2d) 286.

Watts and Henderson Ltd, [1988] OLRB 721.

Mosaic Potash Colonsay ULC and USW, Local 7656 (2012), 218 CLRBR (2d) 44 (Sask); Re WestankWillock and USWA Local 4728, 1987 CarswellSask 720 (LRB).

Northstar Lumber v USWA Local 1-424 (2006), 128 CLRBR (2d) 1 (BC).

In the unionized context, see e.g. Grain Workers, supra note 12; Natrel Inc and Milk and Bread Drivers, Dairy Employees, Caterers and Allied Employees, Teamsters Local Union No 647 (Evely), Re (2001), 64 CLAS 248 (Ont LRB); British Columbia Hydro and Power Authority and OPEIU, Local 378 (Norton) (Re) (2003), 117 LAC (4th) 419. 
constitute breach or even repudiation of the employee's contract of employment, absent an express contractual term allowing them to do so. ${ }^{55}$

\section{Sympathetic ACtion: A ReView Of ExCEPTIONS}

However, there have been and are exceptions in Canadian law to the general bar on sympathetic action. Two types of sympathetic action - refusal to cross a picket line, and refusal to handle "hot cargo" - have been the subject of significant consideration across Canada. Each has been subject to statutory provisions and specifically addressed within many collective agreements due to its centrality to sympathetic action and to union solidarity.

Saskatchewan, for example, did not have a definition of "strike" in its legislation until 1994. ${ }^{56}$ As a result, prior to the 1994 statutory amendment, the common law definition of "strike" governed, ${ }^{57}$ and it was not a "strike" if workers in Saskatchewan refused to cross a picket line. ${ }^{58}$

In British Columbia prior to 1984, if workers refused to cross a picket line out of a feeling of solidarity for the striking workers, that would not be a "strike" under the British Columbia legislation. ${ }^{59}$ This was by virtue of the definition of "strike," ${ }^{\prime 60}$ which required that a "strike" under the Labour Code be for the purpose of "compelling" an "employer" — whether the workers" own or another - to "agree to terms or conditions of employment." "61 As a result, the British Columbia Labour Relations Board held that, for example, strikes in support of a "national day of protest" were not "strikes" under the Code. ${ }^{62}$ It is notable that the British Columbia Board in MacMillan Bloedel came to the exact opposite conclusion, as did the Alberta Board in McGavin Foods. The distinction is now moot, however, as the British Columbia definition was amended in 1984 to reflect an "effects-based" definition. ${ }^{63}$

The New Brunswick Supreme Court held in one case that it was not a "strike" when workers refused to cross picket lines, ${ }^{64}$ but that case dealt with a "common employer" situation and, more significantly, does not appear to have been followed in subsequent cases in that province. ${ }^{65}$

Peter Barnacle et al, Employment Law in Canada, 4th ed (Markham: LexisNexis Canada, 2005) (looseleaf updated September 2011, release 33) vol 2, ch 11 at 11-61. See also KD Ewing, The Right to Strike (New York: Oxford University Press, 1991) at 14; Langille, supra note 36 at 368-69; Reference re Public Service Employee Relations Act (Alta), [1987] 1 SCR 313 at 407-409, McIntyre J [Alberta Reference]. Note that in the unionized context, at least, the value of such a term in a collective agreement is questionable, as will be discussed below.

56 The Trade Union Act, RSS 1978, c T-17, as amended (in this regard) SS 1994, c 47, s 3(d), repealed by The Saskatchewan Employment Act, SS 2013, c S-15.1, s 6-1(1)(n).

57 Re Dominion Bridge Co and United Steelworkers of America, Local 5917 (1977), 15 LAC (2d) 295 (Sask).

Re Wascana Hospital, [1983] Jan Sask Labour Rep 41.

MacMillan, Bloedel Packaging Limited (1975), [1976] CLRBR 100 at 103 [MacMillan Bloedel]. Labour Code, RSBC 1979, c 212, s 1(1).

Ibid.

British Columbia Hydro and Power Authority v International Brotherhood of Electrical Workers, Locals 258 and 213 (1976), 8 CLLC 342 (BC LRB).

63 Labour Code Amendment Act, 1984, SBC 1984, c 24, s 1.

$64 \quad$ Furness Withy \& Co Ltd v Local 273, International Longshoremen's Association (1974), 44 DLR (3d) 758 (NBQB).

Adams, supra note 33 at 11-6. 
Currently, British Columbia appears to exempt from the definition of "strike" a refusal to cross a legal picket line: "[a strike] does not include...a cessation, refusal, omission or act of an employee that occurs as the direct result of and for no other reason than picketing that is permitted under this Code." ${ }^{\text {} 66}$ The section does not appear to have been considered in its present form, ${ }^{67}$ which leaves the question open as to whether refusing to cross a picket line raised by another group of workers is "a result of and for no other reason than picketing."

The British Columbia Board also allows workers to refuse to handle "hot cargo" if their collective agreement provided them the right to do so despite the "objective" 1984 amendments to the British Columbia Code. ${ }^{68}$

Seemingly alone in Canada, the Manitoba Labour Relations Act provides explicit protection for an employee who takes sympathetic action, as follows:

\begin{abstract}
An employee who is in a unit of employees of an employer in respect of which there is a collective agreement in force and who refuses to perform work which would directly facilitate the operation or business of another employer whose employees within Canada are locked out or on a legal strike is not by reason of that refusal in breach of the collective agreement or of any term or condition of his employment and is not, by reason of that refusal, subject to any disciplinary action by the employer or the bargaining agent that is a party to the collective agreement. $^{69}$
\end{abstract}

The wording of the Manitoba statute is remarkably broad, and conceivably covers not merely refusal to handle hot cargo, but also refusal to cross a picket line and refusal to do work at one's own workplace that might, for instance, supply goods to a struck workplace. Despite its broad wording, however, this section is subject to a number of limitations. It expressly sets out that an employer is not required to pay an employee for work not done, ${ }^{70}$ which seems neither surprising nor unreasonable. However it also does not allow an employee to refuse work that would facilitate production at a struck or locked-out workplace that is run by the same employer, even if that other workplace is in a different province. ${ }^{71}$ The section specifies facilitating production of another employer, not another workplace. In addition, it specifies that the action must be in support of employees "within Canada," hence, the action cannot be in sympathy with foreign workers. ${ }^{72}$

BC Labour Relations Code, supra note 30, s 1(1).

See Labatt Brewing Co Ltd (Re), [2003] BCLRBD No 228 (QL) (the employer brought an application before the B.C. Labour Relations Board to forestall expected refusal by members of the Brewery, Winery and Distillery Workers' Union to cross an anticipated picket line - at the British Columbia worksite - by striking workers from the employer's Montreal operation. The Board, however, upheld the Union's preliminary objection that the application was premature, and did not rule on the substantive issues).

East Kootenay Newspapers Ltd (Re), [1987] BCLRBD No 113 (QL) [Re East Kootenay Newspapers], (a refusal to handle advertisements from a company subject to a "hot" declaration was ruled not to be an illegal strike due to a clause in the collective agreement that allowed workers to refuse struck work, to refuse to cross a picket line, and/or to refuse to handle "hot" goods). See also Schindler Elevator Corp and IUEC, Local 82, [2014] 240 CLRBR (2d) 58 (BC).

MB Labour Relations Act, supra note 30, s 15(1).

Ibid, s 15(5).

Vale Inco Ltd (Re), [2010] MLBD No 14 (QL); Molson Breweries (Winnipeg) and United Food \& Commercial Workers International Union, Local 330W, [1991] MLBD No 18 (QL).

England, "Peace Obligation," supra note 21 at 585. 
More significantly, however, the protection is exclusively individual. It does not extend to the union to which the employee may belong, as sympathetic action that is taken collectively and urged or co-ordinated by the employee's union could constitute an illegal work stoppage under the Act. ${ }^{73}$ It is not clear if a group of workers that undertakes sympathetic action, absent encouragement from union officials, would be in breach of the Act's peace obligation; it seems likely that such activity would be considered an illegal strike.

Another exception (though an inconsistent and apparently unreliable one) can be found where a collective agreement expressly allows workers to engage in sympathetic action. Courts (but not labour boards) have consistently held that it is not possible to contract out of the peace obligation; for instance in Ontario ${ }^{74}$ and Alberta, ${ }^{75}$ where clauses that allow for sympathetic action cannot authorize a strike because they contradict the statutory prohibition on mid-term strike action. Similarly, in British Columbia, a collective agreement clause that allows explicitly for mid-term strike action is prohibited ${ }^{76}$ (however a clause or clauses that relate to the scheduling of "work" can arguably be upheld because if work is not scheduled then there can be no cessation of work by the union). ${ }^{77}$ Historically, a clause allowing for sympathetic action may have, in some cases, insulated employees from discipline or their union from damages at arbitration ${ }^{78}$ (though it would protect neither from statutory penalties or fines), but this does not appear to have been a consistent or reliable interpretation among arbitrators. $^{79}$

\section{SECTION 2 OF THE CHARTER}

The ability of unions and workers to take sympathetic action in Canada is thus very limited. As stated at the beginning of this article, such strict limitations are not defensible under the various freedoms in section 2 of the Charter. However, each freedom provides a different lens through which we can view both statute and the common law. These distinctions remain relevant; MPAO and SFL have changed the landscape regarding freedom of association under section 2(d), but SFL gives only the briefest reference to freedom of expression, and in neither case were conscientious or religious freedom under section 2(a) raised (or, arguably, relevant).

For instance, under the current law, freedom of association is (arguably) certainly infringed by the existing bar on collective sympathetic action. However, freedom of expression and conscience are also infringed, as without collective exercise, each freedom is essentially impotent in this context. Yet a law that would vest the right to engage in sympathetic action only in trade unions rather than individual workers (which the

Retail Store Employees Union Local 832 v Canada Safeway Ltd (1979), 100 DLR (3d) 479 (Man QB). Nelson Crushed Stone and United Cement Lime \& Gypsum Workers’ International Union, Local 494 (1977), [1978] 1 CLRBR 115 (Ont).

McGavin Foods, supra note 46.

Macdonalds Consolidated Ltd v RWDSU Loc 580, [1976] 2 CLRBR 292 (BC).

Geoffrey J England, "Statutory Definition of 'Strike': Whether Honouring Picket Lines Constitutes a 'Strike" (1979) 11:3 Ottawa L Rev 771 at 790 [England, "Statutory Definition"].

England, "Peace Obligation," supra note 21 at 573-74. See also Re East Kootenay Newspapers, supra note 68 (regarding a "hot cargo" clause).

See Kingston Whig-Standard, supra note 48; Ronald M Snyder, Collective Agreement Arbitration in Canada, 4th ed (Markham: LexisNexis Canada, 2009) at 825. 
International Labour Organization (ILO) has said is acceptable) ${ }^{80}$ might adequately protect the freedom of association while not providing adequate protection to the more individual freedoms of conscience and expression. Similarly, the existence of alternative dispute resolution mechanisms may be useful in justifying limitations on a right to strike (while not falling within the scope of freedom of association itself), ${ }^{81}$ but might not satisfy the expressive or conscientious interests of sections 2(a) and (b).

On the other hand, I do not wish to be seen as arguing that each freedom is a "watertight compartment." Sympathetic action may be protected under one, two, or all three of these freedoms. This is, as has been noted by Justice La Forest of the Supreme Court in Lavigne, to be expected: Charter rights and freedoms overlap and the fact that one right or freedom may apply does not necessarily exclude another. ${ }^{82}$

Within all of these fundamental freedoms is a common theme, however - recognition and protection of individual worth: "[h] uman dignity, equality, liberty, respect for the autonomy of the person and the enhancement of democracy are among the values that underly the Charter." 83

Each freedom can be understood as a distinct aspect of an individual's dignity and autonomy. The freedoms of conscience and religion are part of a person's moral and philosophical core ${ }^{84}$ Freedom of expression includes thought and opinion, but addresses the importance of vibrant discussion within society. Section 2(b) has an inherently interactive element, ${ }^{85}$ and I suggest that the line between section 2(a)'s conscience, and 2(b)'s thought, belief and opinion, should be understood as the distinction between matters that are conscientious and those that are expressive, rather than (as some have done) attempting to draw a distinction between faith and reason, or between rational and irrational beliefs. ${ }^{86}$ Finally, freedom of assembly and freedom of association (2(c) and 2(d) of the Charter, respectively) must necessarily involve other individuals to be meaningful.

International Labour Office, Freedom of Association: Digest of decisions and principles of the Freedom of Association Committee of the Governing Body of the ILO, 5th revised ed (Geneva: International Labour Office, 2006) [ILO Digest] ("[i]t does not appear that making the right to call a strike the sole preserve of trade union organizations is incompatible with the standards of Convention No. 87. Workers, and especially their leaders in undertakings, should however be protected against any discrimination which might be exercised because of a strike and they should be able to form trade unions without being exposed to anti-union discrimination" at para 254).

81 The Supreme Court in SFL, supra note 4, opined that alternative dispute resolution mechanisms were "generally not associational in nature and may, in fact, reduce the effectiveness of collective bargaining processes over time" (ibid at para 60) and suggested such mechanisms should be considered only when considering, under section 1 of the Charter, whether limitations on a section 2(d) right were justified - not at the infringement stage.

Lavigne v Ontario Public Service Employees Union, [1991] 2 SCR 211 at 279.

$B C$ Health Services, supra note 9 at para 81 [citations omitted].

See e.g. $R v$ Edwards Books and Art Ltd, [1986] 2 SCR 713[Edwards Books] (wherein the freedoms in section 2(a) are described as protecting individuals from government interference with "profoundly personal beliefs that govern one's perception of oneself, humankind, nature, and, in some cases, a higher or different order of being. These beliefs, in turn, govern one's conduct and practices" at 759). See also Timothy Macklem, Independence of Mind (Oxford: Oxford University Press, 2006) at 68-69.

85 Richard Moon, The Constitutional Protection of Freedom of Expression (Toronto: University of Toronto Press, 2000) at 21.

86 See e.g. Justice Linden's reasons (concurring in the result) in Roach v Canada (Minister of State for Multiculturalism and Citizenship) (CA), [1994] 2 FCR 406 [Roach] ("[w]e are dealing here in the realm of reason, not of faith, nor of morality. It is obvious that there are no sharp dividing lines here; these matters may blur into one another, making them difficult to differentiate" at 430). 
I suggest that as one moves "outward" from conscience to expression to association, the more "internal" freedoms, as well as being inherently important, strengthen the more "external" freedoms ${ }^{87}$ Given the importance of conscience to individual self-fulfillment and human dignity, for example, expression that gives voice to matters of conscience is arguably of greater significance than expression that does not. Similarly, association that is the collective exercise of freedom of conscience, or freedom of expression, is arguably of greater significance than associative activities that do not involve other Charter freedoms.

I hasten to add that, in suggesting this approach towards freedom of association in particular, I am not adopting the "derivative" approach to freedom of association, where "freedom of association is recognized insofar as it supports other constitutional rights" but is not constitutionally protected beyond that ${ }^{88}$ The Supreme Court in MPAO has strongly endorsed freedom of association as an independent right — "not derivative" of other freedoms, but rather "an independent right with independent content, essential to the development and maintenance of the vibrant civil society upon which our democracy rests." $" 89$ I suggest this is in keeping with the "emanating" view of section 2 freedoms.

Rather, freedom of association should be viewed through the purposive analysis taken by the Supreme Court in MPAO, ${ }^{90}$ and (I suggest) associational activities that do support or involve other constitutional rights are closer to core protected associational interests. As such, the involvement of other constitutional rights may serve to bring associational activity within the ambit of section $2(\mathrm{~d})^{91}$ but may also be relevant in evaluating limitations on that activity under section 1. The Supreme Court has suggested that the "nature of a given associational activity and its relation to the underlying purpose of s. 2(d)" is potentially relevant to the section 1 analysis in a freedom of association case, just as the nature of expression (for example, hate speech) may be evaluated in its distance from the "core values" behind that freedom. ${ }^{92}$

Because sympathetic action, in my view, potentially invokes all of conscience, expression, and association, the three freedoms build on each other - not because they are of different levels of importance, but because they are of different character, each representing a different and profound aspect of the individual.

Thanks to Professor Mark Carter for his observation about the "emanating" nature of section 2. MPAO, supra note 3 at para 53 .

Ibid at para 49.

Ibid at paras 54-55.

Ibid at para 59 (the Court recognized that not all associational activity will be protected; violence, for instance, is not protected).

Ibid at para 61. See also Saskatchewan (Human Rights Commission) v Whatcott, 2013 SCC 11, [2013] 1 SCR 467 at paras 112,114 [Whatcott]. 


\section{A. Freedom of Conscience And Sympathetic ACTion}

While freedom of religion under section 2(a) of the Charter has been judicially considered a number of times, ${ }^{93}$ freedom of conscience has, for the most part, received only cursory treatment by Canadian courts. ${ }^{94}$ It is perhaps odd that this is the case. After all, it would seem that the concept of conscience generally is broader than the concept of religion. ${ }^{95}$ What is relevant to the present argument, however, is that the language used in freedom of religion cases has generally been general enough to encompass secular beliefs.

For instance, in Big M Drug Mart, Justice Dickson (as he then was) described freedom of conscience and freedom of religion as forming "a single integrated concept" in section 2(a). ${ }^{96}$ Freedom is characterized by the absence of coercion or constraint and is founded upon "respect for the inherent dignity and the inviolable rights of the human person." 97 It means that "no one is to be forced to act in a way contrary to his beliefs or his conscience." $" 98$

Similarly, in Edwards Books, the language used by the Supreme Court does not require that profound beliefs have a religious source; it is the nature of the beliefs, not their origin, that is important. ${ }^{99}$ However, it also seems clear that conscience, in the Charter context, is interpreted to refer to beliefs that are, if not religious, then of almost-religious character. ${ }^{100}$ Edwards Books also reaffirms the individual character of section 2(a) and adds the "trivial and insubstantial" hurdle for Charter review of freedom of religion, which was applied by Justice Linden in his reasons in Roach regarding freedom of conscience. ${ }^{101}$

From the freedom of religion cases since Big M Drug Mart, we can draw certain principles that, again, seem equally applicable to questions of secular conscience. In order to claim the protection of section 2(a), applicants must demonstrate that their freedom has, in fact, been infringed; it is not sufficient to simply state that they feel it has been infringed. ${ }^{102}$ They must demonstrate that the infringement is not trivial or insubstantial. ${ }^{103}$ They must demonstrate that they are sincere in their beliefs. ${ }^{104}$ The court will not serve as an arbiter of dogma, ${ }^{105}$ nor is

Notable examples include $R v$ Big M Drug Mart Ltd, [1985] 1 SCR 295 [Big M Drug Mart]; Edwards Books, supra note 84; Ross v New Brunswick School District No 15, [1996] 1 SCR 825 [Ross]; Trinity Western University v British Columbia College of Teachers, 2001 SCC 31, [2001] 1 SCR 772; Syndicat Northcrest v Amselem, 2004 SCC 47, [2004] 2 SCR 551 [Syndicat Northcrest]; Multani v Commission scolaire Marguerite-Bourgeoys, 2006 SCC 6, [2006] 1 SCR 256 [Multani]; Alberta v Hutterian Brethren of Wilson Colony, 2009 SCC 37, [2009] 2 SCR 567 [Hutterian Brethren]; and most recently Loyola High School v Quebec (Attorney General), 2015 SCC 12, 382 DLR (4th) 195. For a recent discussion of freedom of conscience, see Mary Anne Waldron, Free to Believe: Rethinking Freedom of Conscience and Religion in Canada (Toronto: University of Toronto Press, 2013).

Macklem, supra note 84 at viii (though it should be noted that Macklem does view conscience and religion as distinct concepts).

Supra note 93 at $345-46$.

Ibid at 336 .

Ibid at 337.

Supra note 84 ("[t]he purpose of s. 2(a) is to ensure that society does not interfere with profoundly personal beliefs that govern one's perception of oneself, humankind, nature, and, in some cases, a higher or different order of being. These beliefs, in turn, govern one's conduct and practices" at 759).

Peter Hogg, Constitutional Law of Canada, 5th ed (Toronto: Carswell, 2007) (loose-leaf updated 2013, release 1), vol 2 ch 42 at 42-3.

Supra note 86.

SL v Commission scolaire des Chênes, 2012 SCC 7, [2012] 1 SCR 235 at paras 23-25 [SL].

Edward Books, supra note 84.

SL, supra note 102 at paras 51-52.

Syndicat Northcrest, supra note 93 at para 50 . 
it necessary that the individual's beliefs coincide with established religious precepts. ${ }^{106}$ The court will, however, question the strength of an applicant's belief — not whether the practice is mandatory or voluntary, but rather how important the practice is to the claimant. ${ }^{107}$

With those interpretive principles in mind, we can turn to the treatment of conscience, specifically, in Canadian courts. Most of the case law dealing with freedom of conscience has, perhaps surprisingly, arisen in taxation law, where taxpayers have had conscientious objections to particular areas of government spending and have sought an exemption from a portion or all of their income tax as a result. ${ }^{108}$ There has been some consideration of freedom of conscience in immigration law, usually where individuals have had conscientious objections to taking the oath of citizenship required under the Citizenship Act ${ }^{109}$ and, in particular, to the portion of the oath where a prospective citizen must swear or affirm that they "will be faithful and bear true allegiance to Her Majesty Queen Elizabeth the Second, Queen of Canada, Her Heirs and Successors."110 A similar, secular objection was unsuccessfully raised by a military officer to displays of allegiance to the Queen. ${ }^{11}$

Conscience was also raised in Maurice v. Canada (Attorney General), ${ }^{112}$ where the Federal Court held that, because vegetarian meals were provided to inmates with religious objections to eating meat, and because section 2(a) provides for freedom of conscience as well as freedom of religion, "a similar entitlement for a vegetarian diet exists based on the right to freedom of conscience." 113

While freedom of conscience was given serious consideration in Maurice, conscientious objection in the context of either taxation or immigration have generally fared badly in the courts. In the examples given above, the complaints have universally been dismissed, often with only brief reasons; few of these cases have given detailed consideration to freedom of conscience.

The leading definition of conscience, therefore, remains that set out by Justice Bertha Wilson in her concurring reasons in $R$. v. Morgentaler:

[I]t would be my view that conscientious beliefs which are not religiously motivated are equally protected by freedom of conscience in s. 2(a). In so saying I am not unmindful of the fact that the Charter opens with an affirmation that "Canada is founded upon principles that recognize the supremacy of God...." But I am

Ibid at para 53. See also Multani, supra note 93; Ross, supra note 93 (regarding a belief that Christianity mandated anti-Semitism); Hutterian Brethren, supra note 93 (regarding a belief that the Second Commandment forbade individuals from having their photograph taken). Syndicat Northcrest, ibid at para 51.

108 See e.g. Norejko v R, 2004 TCC 829, [2005] 1 CTC 2765 (abortion); Petrini (M) v Canada, [1995] 1 CTC 200 (FCA), leave to appeal to SCC refused, 24433 (25 November 1994) (military spending); Woodside (D) v Canada, [1993] 2 CTC 2348 (TCC) [Woodside] (military spending); Hertzog (S) $v$ MNR, [1991] 1 CTC 2529 (TCC) (military spending); O'Sullivan v MNR (TD), [1992] 1 FC 522 (abortion); J Prior v Canada, [1989] 2 CTC 280 (FCA) (military spending). RSC 1985 , c C-29, ss 3(1)(c), 24, schedule.

See e.g. Roach, supra note 86; Bryce Edwards, "Let Your Yea be Yea: The Citizenship Oath, the Charter, and the Conscientious Objector" (2002) 60:2 UT Fac L Rev 39 at 83 (this is as likely to arise from a religious belief, such as a belief a person owes allegiance only to God as from a secular one, such as political republicanism).

111 Chainnigh v Canada (Attorney General), 2008 FC 69, 322 FTR 302.

112210 DLR (4th) 186 (FCTD) [Maurice].

$113 \quad$ Ibid at para 12. 
also mindful that the values entrenched in the Charter are those which characterize a free and democratic society.

It seems to me, therefore, that in a free and democratic society "freedom of conscience and religion" should be broadly construed to extend to conscientiously-held beliefs, whether grounded in religion or in a secular morality. Indeed, as a matter of statutory interpretation, "conscience" and "religion" should not be treated as tautologous if capable of independent, although related, meaning. ${ }^{114}$

Justice Linden in Roach followed Justice Wilson's reasons, ${ }^{115}$ and while the majority in Roach came to a different result, they accepted Justice Linden's reasoning in relation to section 2(a). ${ }^{116}$ As mentioned above, Justice Linden attempted to draw a distinction between "profound moral and ethical beliefs," on the one hand, and "political and other beliefs" on the other. To repeat my earlier argument, I believe a more fruitful approach to sections 2(a) and (b) would be to view section 2(b) as protecting the interactive aspects of expression and promoting dialogue within society. Regardless of one's approach to section 2(a), however, I suggest that freedom of conscience does have application to sympathetic action.

In the area of labour law, freedom of conscience has received only the briefest of glances and, generally speaking, only at the administrative tribunal or lower court level, and even then has been rarely argued or formed the basis for a decision. While Justice Evans noted in Grain Workers that trade unionists regard it as an "ethical obligation" to not cross another union's picket line, he interprets this only in the context of freedom of expression promotion of the value of promoting diversity in forms of individual self-fulfillment and human flourishing. ${ }^{117}$

Because it will later be argued that freedom of expression also protects the right to sympathetic action, it is not fatal to recognition of such a right if sympathetic action is not a matter of conscience. However, to a certain extent, relegating beliefs in union solidarity to mere political beliefs would seem to ignore the role of such beliefs as part of the moral core of some trade unionists.

That moral core can manifest in the initiation oaths within trade unions. Many unions still include initiation rituals for new members, and include oaths therein. ${ }^{118}$ These are generally not oaths to a higher power but, rather, to one's "honour," or simply phrased as a solemn promise. ${ }^{119}$ Initiation rituals are generally done publicly and witnessed. Like a citizenship

[1988] 1 SCR 30 at 178-79 [Morgentaler] [emphasis added].

Supra note 86 at 426 .

Ibid at 411-12.

Supra note 12 at para 57 .

See e.g. Service Employees International Union, SEIU 2012 Constitution and Bylaws (Washington, DC: SEIU, 2012), online: <www.seiu.org/15728.SEIU-Constitution-Bylaws-2012.pdf > at 45; Canadian Union of Public Employees, Constitution 2011 (Ottawa: CUPE, 2011), online: <cupe.ca/updir/ Constitution2011_english.pdf $>$ at B.8.4; Communications, Energy and Paperworkers Union of Canada, Constitution of the Communications, Energy and Paperworkers Union of Canada (Montreal: CEPU, 2012) art 21.01, online: $<$ http://cep.unifor.org/sites/cep.ca/files/docs/en/130117-Constitution-2012.pdfs'. Notably, however, invocation of a higher power is no longer considered necessary to bind one's conscience in court: see $R v$ Khan, [1990] 2 SCR 531. 
oath, a union initiation is a "public ceremony, with personal, religious, social and political ramifications." 120 These are public declarations of allegiance and principle, meant to bind the conscience. This is not to say that merely taking an oath renders everything one does to an act of conscience. Were that so, one can easily imagine oaths being taken to justify any number of dubious pursuits. However, union oaths demonstrate the historical importance of union solidarity and that, at the very least, there can be a moral component to respecting a picket line.

That does not mean the decision to undertake sympathetic action is necessarily irrational. Timothy Macklem views conscience as part of our "rational personality." ${ }^{21} \mathrm{He}$ views conscience as a source of reason rather than exclusive of reason. ${ }^{122}$ Rationality is not a bar to profundity; rather, the two are inseparable. Similarly, Dianne Pothier has argued that respecting a picket line may be instinctive, but not irrational. ${ }^{123}$ While Pothier's argument deals with the freedoms of expression and association, it seems entirely applicable to freedom of conscience.

Where the worker is not represented by a union, the conscientious aspects seem even more pronounced. A non-unionized worker may have been a union member previously, or may even still be one; some unions allow members to maintain membership after they have ceased employment in a bargaining unit for which that union holds certification. Or a non-unionized worker may never have signed a union card and may never have taken an oath; they have no basis for sympathetic action beyond their own beliefs. Regardless, they do not have the protections within their own workplace that a unionized worker has. ${ }^{124}$ They also will generally have to make a decision to respect a picket line on their own, without leadership or support from a union. This leaves non-unionized workers particularly vulnerable to retaliation by their employer if they choose to engage in sympathetic action. Even where authorized on an individual basis (as in Manitoba), workers may face a loss of pay for work not performed and no doubt subtle and less-than-subtle pressure from their employer.

The choice to respect a picket line is not consequence-free even if that choice is permitted in law. Where a worker chooses to take sympathetic action (other than in situations such as refusing to cross a picket line due to fear for their personal safety, of course) it seems almost certain that for many, that choice will be taken as a matter of conscience.

Commission Scolaire des Chênes requires that the applicant prove, on a balance of probabilities, that a practice or belief exists that has been infringed. ${ }^{125}$ If sympathetic action is a matter of conscience, then any statutory restriction on sympathetic action potentially

Edwards, supra note 110 at 67.

Supra note 84 at $98-99$.

Ibid at $86-87$.

Dianne Pothier, "Twenty Years of Labour Law and the Charter" (2002) 40:3 Osgoode Hall LJ 369 at 391-92.

While retaliation against a worker for union activity is almost certainly an unfair labour practice under Canadian labour legislation, it is not clear that refusal to cross a picket line would constitute protected activity under various labour relations legislation, and such refusal or to otherwise refuse to perform one's duties - as noted previously - will likely be considered insubordination, and therefore grounds for discipline. Non-unionized workers will also not have access to a grievance procedure or (if dismissed) the right to reinstatement.

SL v Commission scolaire des Chênes, 2012 SCC 7, [2012] 1 SCR 235 at para 23. 
infringes section 2(a). To believe strongly in solidarity and yet to be required to cross a picket line for fear of statutory penalty, for instance, is an actual infringement of a deeplyheld moral belief. The believer is forced to act in direct opposition to their moral code.

Is the infringement not trivial or insubstantial? The majority in Grain Workers gives little faith that the courts will give much credence to unionists' claims that their Charter freedoms are infringed by the peace obligation. Yet the infringement upon unionists' freedom of conscience is a direct interference with their ability to exercise that Charter freedom. Indeed, without the right to sympathetic action, solidarity as an expression of freedom of conscience is essentially impotent. The ability to express support for strikers through other means, such as writing letters to the editor or joining the picket line on one's own time (as Justice Evans suggested in Grain Workers) may address the interests inherent in section 2(b), but not the basic affront to one's conscience at being forced to do something that one believes is morally wrong.

The evaluation of sincerity may be problematic. However, the Supreme Court specifically rejected the "objective" test suggested by Justice Bastarache in Syndicat Northcrest. ${ }^{126}$ As a result, the Courts should keep to a minimum their assessment of an individual's sincerity of belief. Therefore, while a court can inquire into an individual's sincerity, it should not pass judgment on the validity of beliefs nor whether such beliefs are in keeping with others' interpretation of religious precepts. Applied to sympathetic action, the evaluation seems quite straightforward, especially given the prevalence of "solidarity" as the guiding principle for most trade unions.

Yet the application of freedom of conscience, as perhaps the most profoundly individual right, to sympathetic action presents a very basic problem: what impact should it have on the law? Individual action is not a "strike" and therefore does not contravene the peace obligation. When sympathetic action is undertaken by union members collectively - either refusing to cross a picket line or engaging in a full-on sympathy strike - the peace obligation is infringed. But the associational aspects can be dealt with under section 2(d). Nonetheless, I suggest that freedom of conscience still supports a change to the peace obligation.

As mentioned above, freedom of conscience can bolster a claim under sections 2(b) and (d). Expressive or associational activity taken on conscientious grounds is arguably closer to the core of the Charter than is associational activity taken in the context of leisure (such as a golf club, for instance). Indeed, conscientious (or at least religious) activity lies at the very heart of freedom of association, as associational freedom was historically recognized to protect religious minorities. ${ }^{127}$

Historically, the British Columbia Board would not infer a common understanding from a refusal to cross a picket line. ${ }^{128}$ The British Columbia cases suggest that solidarity is instinctive, moral, perhaps even irrational. The Alberta Board, on the other hand, has viewed 
refusal to cross as a rational exercise in enlightened self-interest. ${ }^{129}$ The interpretation of solidarity is key - and if it is viewed, as the British Columbia Board once did, as a moral decision on the part of trade unionists, the peace obligation infringes not only the associational rights of the workers but also their freedom of conscience. Just as the broad rule prohibiting weapons in school violated a Sikh student's section 2(a) right to carry his kirpan in Multani, a statutory fine levied against a conscientious trade unionist would arguably violate that worker's section 2(a) right to engage in sympathetic action.

Recognizing the conscientious aspects of sympathetic action could arguably serve as proof that the decision not to cross a picket line was undertaken individually, of course, but action based on individual conscience does not preclude that action also being undertaken pursuant to a common understanding among like-minded individuals - and, hence, an illegal strike. Nonetheless, inferring a common understanding (as the Alberta Board does) as the basis for an injunction or fine does seem to ignore the impact of individual conscience and as such may infringe a conscientious trade unionist's section 2(a) freedom. That being said, it would seem the real problem in such a situation is that legislation will deem such activity, once common understanding is inferred, as an illegal strike — perhaps a matter more for freedom of association analysis, as discussed below, than for freedom of conscience.

It could be argued, of course, that emphasis on "personal philosophy" may "make it too easy to escape the statutory peace obligation." 130 In any given sympathetic action situation, workers will undertake sympathetic action (or choose not to) for a variety of reasons. It is potentially unwieldy to ask the courts or labour arbitrators to inquire individually about every striker's motive in a given strike situation. ${ }^{131}$ However, the courts have not shied away from taking individual applicants' beliefs into account in situations concerning statutory restrictions or prohibition on religious practices. ${ }^{132}$ As one commentator has noted, "there seems to be no reason in principle why a genuine and honest belief in union solidarity should not constitute evidence of individual decision-making so long as the employee's testimony is credible." 133 The potential difficulties should not preclude judicial oversight of labour relations legislation, nor should they prevent an evolution of the common law to conform to Charter values.

In the end result, as the Supreme Court noted in Edwards Books, "[b]y its nature, legislation must, to some degree, cut across individual circumstances in order to establish general rules."134 It is more desirable that, when developing general rules, laws err on the side of allowing the exercise of Charter rights than restricting them.

McGavin Foods, supra note 46.

England, "Statutory Definition," supra note 77 at 788.

That said, if unionized workers are disciplined during a strike for respecting a picket line, it seems likely that, in any grievances brought by the union regarding that discipline, an arbitrator would be called upon to do just that in any event, even absent the Charter argument.

See e.g. Hutterian Brethren, supra note 93 (objections to mandatory photo identification); Multani, supra note 93 (the right to carry a kirpan (a ceremonial knife) at school by a Sikh student); Edwards Books, supra note 84 (the right for retailers who observed Saturday Sabbath to remain open on Sunday). England, "Statutory Definition," supra note 77 at 788-89.

Supra note 84 at 777. 


\section{B. FREEDOM OF CONSCIENCE, THE LAW OF CONTRACT, AND THE LAW OF TORT}

The Supreme Court has urged caution in applying Charter values to interpretation of the common law. ${ }^{135}$ At the same time, the Court has stated: "The law of tort may itself be expected to develop in accordance with Charter values, thus assuring a reasonable balance between free expression and protection of third parties." $" 136$ There seems no principled reason why the law of contract should not also adapt to reflect Charter values.

With the caution of the courts in mind, however, I do not suggest that the application of freedom of conscience to sympathetic action warrants a broad intrusion into the common law rights and privileges of the employer. However, I submit that an interpretation based on Charter values does require some amendment to the common law as it applies to sympathetic action.

There is no explicit protection for sympathetic action at common law or in statute; quite the reverse. A worker's reasons for refusing work may factor into the penalty applied; in the modern context where courts are more conscious of the idea of "proportionality" in the context of discipline, ${ }^{137}$ it is possible that a court would find that absence from work due to sympathetic action does not warrant dismissal. That mitigates the extent of discipline, though the conduct may still be worthy of discipline.

Similarly, workers who engage in sympathetic action may face the prospect of liability in tort. For instance, the old tort of conspiracy to injure may have joined restraint of trade on the dustbin of labour history, ${ }^{138}$ but other torts remain that can have an impact on strikes and strikers. The Supreme Court in Pepsi-Cola noted that torts such as trespass, intimidation, nuisance, defamation, and inducing breach of contract can be used to protect property interests and access to private premises. ${ }^{139}$ The Charter does not grant immunity to criminal or tortious conduct, just as freedom of expression does not grant immunity to defamation claims. As Harry Arthurs notes, "[a]nyone familiar with the common law or criminal law of picketing ... would recognize how drastic a restriction lies concealed within this apparently modest caveat."

If undertaking sympathetic action is a matter of conscience, then any analysis of its impact on the common law must balance the values at stake, as was done regarding the law of defamation in Hill, or the law regarding secondary picketing in Pepsi-Cola. In Hill, the Court considered "the innate dignity of the individual" as a theme that underlies all Charter rights. ${ }^{141}$ Respect for an individual's strongly-held moral beliefs also promotes the innate dignity of the individual; conscience is as worthy of protection as reputation. The existing state of the law makes no

Hill, supra note 24 at paras 95-96.

RWDSU, Local 558 v Pepsi-Cola Canada Beverages (West) Ltd, 2002 SCC 8, [2002] 1 SCR 156 at para 106 [Pepsi-Cola].

McKinley v BC Tel, 2001 SCC 38, [2001] 2 SCR 161 at para 57.

See e.g. Pepsi-Cola, supra note 136 at para 23.

Ibid at para 73. The Court also notes that the tort of intimidation is less apt in labour relations situations, as picketing has become so familiar that it is not as intimidating as it once was (at para 95).

Harry Arthurs, "Constitutionalizing the Right of Workers to Organize, Bargain and Strike: The Sight of One Shoulder Shrugging” (2010) 15:2 CLELJ 373 at 382 [emphasis in original].

Hill, supra note 24 at para 120 . Ironically, the Charter value in Hill - the innate dignity of the individual - was the basis upon which the Court justified the infringement of the common law of defamation upon the express Charter right, freedom of expression. 
attempt to balance the values at stake. Therefore, it is arguable that individually undertaking sympathetic action should no longer be considered worthy of discipline or dismissal at common law.

Note that I do not suggest that a worker may refuse work without penalty. As the Manitoba statutory provision authorizing sympathetic action suggests, it would not be fair for a worker to be able to refuse work while at the same time expecting to be paid for work not done. In this regard, I submit that Charter values and the balancing of interests within the common law contract of employment would be served by drawing an analogy between the right to sympathetic action at common law and the right to strike under labour legislation. A worker will not be paid for work refused, but will not be further penalized via discipline for insubordination or liability under the "industrial torts."

This approach addresses a number of the considerations put forward by the Supreme Court in Pepsi-Cola:

(1) Conformity to Charter methodology;

(2) Protection of the value of the Charter right in question;

(3) Avoidance of excessive emphasis on protection from economic harm;

(4) Adequate flexibility;

(5) Rationality; and

(6) Balance of power. ${ }^{142}$

Other considerations identified by the Court in Pepsi-Cola - avoidance of the distinction between primary and secondary picketing and avoidance of the distinction between labour and non-labour expression - are of less relevance regarding freedom of conscience. Concerns about the "signalling effect" of the picket line are not really factors regarding conscience except insofar as conscience may be triggered in response to a picket line — not itself an irrational decision, as previously discussed.

The final consideration identified by the Court in Pepsi-Cola, however, may be more problematic. The Court mentions "undue harm to neutral third parties" as a consideration. ${ }^{143}$ The Court found that a prohibition on secondary picketing based on neutral retailers' right to trade presented a number of difficulties, in that it gave no weight to the Charter right in question; it overstated third parties' interests by positing a "fundamental" right to trade in a struck good; it glossed over the fact that third parties are harmed even as a result of primary picketing; it contravened the spirit of the Charter by sacrificing an individual right to the collective good with 
no attempt to balance or reconcile them; and an absolute ban on all secondary picketing was not necessary to protect neutral third parties from wrongful conduct. ${ }^{144}$

These considerations, while dealing with freedom of expression, seem apt to the present argument. The current state of the common law, where workers can be disciplined, dismissed, or sued for engaging in sympathetic action, gives no weight to freedom of conscience. There is no fundamental right of an employer to trade in struck goods. Hence, there is no fundamental right for an employer to demand that a worker take action to facilitate that trade. ${ }^{145}$ Economic harm is already present in any strike, whether or not workers engage in sympathetic action, and the common law sacrifices the individual right of conscience to the perceived collective good of market efficiency rather than seeking to balance and reconcile them.

There is no question that, as the common law presently stands, sympathetic action is potentially tortious, and involves the spreading of a labour dispute. However, the mischiefs that concerned the Court in Pepsi-Cola were damage to property or persons. A simple refusal to perform work that would serve to weaken a strike does not involve such mischiefs.

\section{FreEdom OF CONSCIENCE IN Human Rights LEgiSLATION}

Looking beyond the peace obligation, three jurisdictions in Canada guarantee freedom of conscience in their human rights legislation. ${ }^{146}$ As such, the individual exercise of sympathetic action is arguably directly protected, even absent government action. These statutes apply to private actors as well as public and quasi-public ones.

Human rights legislation, while not truly constitutional, is of a "special character" and should be given a purposive interpretation. ${ }^{147}$ It is "fundamental law intended to apply to all other legislation of the enacting body in the absence of express words in [the] legislation denying it that power." "148 The Saskatchewan and Yukon statutes also expressly provide that they take precedence over other provincial legislation. ${ }^{149}$ Human rights legislation is already deemed to be incorporated into all collective agreements and contracts of employment. ${ }^{150}$

Furthermore, the Supreme Court in Syndicat Northcrest (applying the Quebec Charter) made clear the application of human rights legislation to the law of contract. ${ }^{151}$

Ibid.

An employer may well have a contractual right to insist that workers perform their regular duties if, for instance, the collective agreement or contract of employment specifically forbids sympathetic action. That is a different sort of right than what is under consideration here, however.

The Saskatchewan Human Rights Code, supra note 26, s 4; Quebec Charter, supra note 26, s 3; Human Rights Act, supra note 26, s 4.

Ontario (Human Rights Commission) v Simpsons-Sears Ltd, [1985] 2 SCR 536 ("[human rights legislation] is of a special nature, not quite constitutional but certainly more than the ordinary - and it is for the courts to seek out its purpose and give it effect" at 547).

Scowby v Glendinning, [1986] 2 SCR 226 at 236, aff'g in part (1983), 148 DLR (3d) 55 (Sask CA).

Human Rights Act, supra note 146, s 39; The Saskatchewan Human Rights Code, supra note 26, s 44.

Parry Sound (District) Social Services Administration Board v OPSEU, Local 324, 2003 SCC 42, [2003]

2 SCR 157 ("[h]uman rights and other employment-related statutes establish a floor beneath which an employer and union cannot contract" at para 28).

Hogg, supra note 100 at $42-10,42-14$. 
The analysis already set out regarding freedom of conscience under the Charter therefore seems applicable to freedom of conscience under provincial human rights legislation. The implications are significant. Generally speaking, the employer's ability to discipline workers who refuse to perform work, grounded as that is in the employer's common law right to manage the workplace, is not subject to Charter review as such. ${ }^{152}$ Arguably, where fundamental freedoms appear in provincial legislation, an employer who disciplines or dismisses an employee for taking sympathetic action is violating that employee's freedom of conscience (or expression, or association) and may be subject to a human rights complaint or (in a unionized workplace) a grievance.

\section{FREEDOM OF EXPRESSION AND SYMPATHETIC ACTION}

In R. v. Sharpe, ${ }^{153}$ the Supreme Court set out its understanding of the interests underlying freedom of expression, describing freedom of expression as a fundamental right that makes possible liberty, creativity, and democracy by protecting not only popular expression but also unpopular or offensive expression. Central to the freedom is "the conviction that the best route to truth, individual flourishing and peaceful coexistence in a heterogeneous society in which people hold divergent and conflicting beliefs lies in the free flow of ideas and images." 154

Freedom of expression is not absolute, though because of its importance, the courts should strictly scrutinize any attempts to restrict it. ${ }^{155}$ Its underlying values include "individual selffulfilment, finding the truth through the open exchange of ideas, and the political discourse fundamental to democracy." 156 While some expression is of more significance than others, all forms of expression are important. ${ }^{157}$ In the labour context, freedom of expression can play an important role in "redressing or alleviating the presumptive imbalance between the employer's economic power and the relative vulnerability of the individual worker."158

It is also notable that, in Sharpe, the distinction between "conscience" and "opinion, thought and belief" discussed above becomes clearer. Section 2(b) concerns the manifestation of belief, the exchange of ideas, and political discourse. The interests are interactive and not as strictly personal as the interests protected by section 2(a).

As with the earlier analysis of freedom of conscience, the first step in an analysis of freedom of expression and sympathetic action must begin with determining whether sympathetic action is not merely expression but protected expression. ${ }^{159}$ The second step is to determine if the purpose or effect of government action is to restrict freedom of expression. ${ }^{160}$

See e.g. Delisle v Canada (Deputy Attorney General), [1999] 2 SCR 989 (the exception being where the government is the employer, in which case the Charter may be applied directly).

2001 SCC 2, [2001] 1 SCR 45 [Sharpe].

Ibid at para 21.

Ibid at para 22 .

Ibid at para 23 [citations omitted].

Ibid.

Alberta (Information and Privacy Commissioner) v. United Food and Commercial Workers, Local 401, 2013 SCC 62, [2013] 3 SCR 733 at para 32 [citations omitted]. 
The first principle is that the content of the expression, in itself, cannot determine whether that expression is protected. So long as it is intended to convey meaning, it is prima facie protected. ${ }^{161}$ Therefore, commercial expression is not inherently excluded from section 2(b)'s protection. This is significant to the present discussion; that there is an element of economic self-interest does not mean expression is not protected.

However, recent cases have affirmed that violent expression and expression that advocates violence are not protected by section 2(b). ${ }^{162}$ As noted in Sharpe, certain types of non-violent speech that may harm or dehumanize others fall under section $2(\mathrm{~b})$ as protected speech but may be justifiably limited. ${ }^{163}$

Second, physical activity may or may not be protected as expression, depending on context and motive. ${ }^{164}$ Regardless of intent, however, violence cannot be protected expression. ${ }^{165}$ Sympathetic action inevitably involves action — or, rather, omission; the refusal to cross a picket line or the refusal to perform work that will benefit an employer against its striking employees. Picketing is inherently expressive, as the Supreme Court noted in Pepsi-Cola. ${ }^{166}$ Strikes taken to protest government action are also inherently expressive. ${ }^{167}$ Public sector strikes, in particular, are inherently political ${ }^{168}$ and are "more a political than an economic weapon." And most recently, the Supreme Court recognized that a strike itself, even in the private sector, is an "expressive activity [that is] directly related to the Charter-protected right of workers to associate to further common workplace goals under s. 2(d) of the Charter." 169 After all, communication is the very purpose of a strike, as noted in SFL, and a picket line, as noted in Pepsi-Cola. The economic aspect of the strike is distinct from the expressive content of the picket line, ${ }^{170}$ but the ties between the strike and the picket line are well-recognized. ${ }^{171}$

It does not necessarily follow that refusing to cross a picket line is also expressive. Sympathetic action may be significantly less public than the dispute to which the sympathetic action responds. The mere fact of a worker, or even a group of workers, refusing to cross a picket line, or even more so refusing to handle "hot cargo" within their own workplace, could be seen as potentially a matter of conscience but not a matter of expression. Clearly there is a continuum of sympathetic action; however, I argue that it is all meant to convey meaning and as such falls under section 2(b).

Ibid at 969.

Greater Vancouver Transportation Authority $v$ Canadian Federation of Students - British Columbia Component, 2009 SCC 31, [2009] 2 SCR 295; $R$ v Khawaja, 2012 SCC 69, [2012] 3 SCR 555; Whatcott, supra note 92.

See e.g. $R$ v Keegstra, [1990] 3 SCR 697 (hate speech); $R$ v. Butler, [1992] 1 SCR 452 (pornography). Irwin Toy, supra note 159 at $971-73$.

Ibid at 970 .

Pepsi-Cola, supra note 164 at paras 27, 30, 32-33. See also BCGEU, supra note 1.

BCTF, supra note 38 .

Ibid at para 21. See also ibid at para 37.

SFL, supra note 4 at para 58.

Williams $v$ Aristocratic Restaurants (1947) Ltd, [1951] SCR 762 at 783, Rand JA, in finding that an informational picket did not constitute a "private nuisance" or a criminal offence:

For what conceivable use or purpose would information be furnished if not to win support by the persuasive force of the matter exhibited? The persuasion is not ordinarily or necessarily sought of the person to be compelled; economic pressure is to affect him; but that pressure, quite legitimate by those who exert it, may easily be set in motion by persuasion exercised upon either workmen or the public is a frequent experience of labour controversy.

See e.g. AWR Carrothers, EE Palmer \& WB Rayner, Collective Bargaining Law in Canada, 2nd ed (Toronto: Butterworths, 1986) at 70. 
Justice Evans' reasons in Grain Workers provide a rationale for refusal to cross a picket line as expressive action: "Refusing to cross a picket line is a uniquely powerful means for employees to publicly express their solidarity with strikers," 172 and forcing workers to cross the line can make it appear as if those workers do not support the strike.

Even sympathetic action taken within one's own workplace is inherently expressive, however, and therefore should be considered "protected expression" under section 2(b). Clearly, there is an economic aspect to the action - it is hoped that, by refusing to perform work that benefits the struck employer, that employer's economic position will be weakened and the strikers' economic position correspondingly strengthened. Workers who undertake such action, knowing that they will suffer at least a financial penalty if not discipline, will inevitably have goals beyond their own conscience. They will perhaps mean to persuade other workers to take similar action, as with any boycott. The refusal may be publicized via a public statement from the workers' union, if they are unionized. They may wish to persuade their own employer to pressure the struck employer to settle. Or they may wish to express a broader principle, that is, solidarity with other workers, perhaps as part of individual self-fulfilment, perhaps as an inherent part of public decision-making (as Justice Evans suggested in Grain Workers) or as part of the concept of "industrial democracy." Regardless of motive, it would be quite bizarre for workers to take such action without intending to convey some meaning.

The majority in Grain Workers, however, disagreed with Justice Evans. Both Justices Blais and Ryer found that sympathetic action (or at least refusal to cross a picket line) was not "expression" for the purposes of the Charter. Citing the principles set out in Irwin Toy, ${ }^{173}$ Justice Blais found that refusing to cross a picket line "had neither a social nor political purpose"; it was, rather, "an intrusion into a private contractual dispute." ${ }^{174}$ It promoted neither seeking and attaining the truth, participating in social and political decision-making, or cultivating diversity in the form of individual self-fulfillment and human flourishing (set out in Irwin Toy). Therefore, as the expression did not fall within the type of expression protected by section 2(b), the provision of the Labour Code infringed freedom of expression in neither purpose nor effect. Justice Ryer, in his brief reasons, essentially concurred with Justice Blais' analysis, adding that, in his view, the decision-making in this case related to the private contractual affairs of the Public Service Alliance of Canada (PSAC) employees and the Canada Grain Commission (CGC), and "[d]ecision making that takes place in a private context is ... not within the ambit of 'participation in social and political decision-making' as contemplated by the Supreme Court of Canada in Irwin Toy." 175 Furthermore, the ambit of expression is limited to those with a legal right to participate in the decision-making in question; as the decision-making related to the private dispute between PSAC and the CGC, and members of the Grain Workers' Union (GWU) and International Longshore and Warehouse Union Ship \& Dock Foreman, Local 514 (ILWU) had no legal right to participate in contractual negotiations between PSAC and CGC, the refusal by GWU and ILWU members to cross the picket line was not protected expression. ${ }^{176}$ The fact

\footnotetext{
172 Supra note 12 at para 48, Evans JA.

173 Supra note 159 at 976 . See also Grain Workers, supra note 12 at para 86.

$174 \quad$ Grain Workers, ibid at para 88.

175 Ibid at para 96.

$176 \quad$ Ibid at para 98.
} 
that CGC is a "government emanation" was not sufficient to connect private negotiations with political decision-making. ${ }^{177}$

I accept the reasons of all three Justices in Grain Workers that the purpose of the statutory bar on sympathetic action is to minimize industrial conflict, not to limit expression. Therefore it is necessary to look to the purpose of the expression in question, and whether that expression falls within the core values of section 2(b). I submit that sympathetic action does fall within those core values, and that the effect of the statutory prohibition therefore limits protected expression.

Clearly, this is at odds with the majority decision in Grain Workers. My disagreement with Justices Blais and Ryer is at least partly based on my argument that sympathetic action can be a matter of conscience. As such, if sympathetic action is an expression of a fundamental moral principle on the part of a worker or workers, it would seem inherently worthy of protection under section 2(b) - though of course still subject to potential limitations if those limitations can be justified under section 1 .

On a more basic level, however, I submit that the majority in Grain Workers has interpreted the principles of freedom of expression, as described in Irwin Toy, in a far too limited manner. The principles as described in Irwin Toy were summarized as follows:

(1) seeking and attaining the truth is an inherently good activity; (2) participation in social and political decisionmaking is to be fostered and encouraged; and (3) the diversity in forms of individual self-fulfillment and human flourishing ought to be cultivated in an essentially tolerant, indeed welcoming, environment not only for the sake of those who convey a meaning, but also for the sake of those to whom it is conveyed. ${ }^{178}$

Similarly, in Whatcott the Supreme Court noted that freedom of expression protected, among other things, "the quest for truth, self-fulfillment, and an embracing marketplace of ideas."179

Certainly, matters of conscience would seem to fall within the seeking and attainment of truth, even if it be a moral "truth." Refusal to perform work in the name of union solidarity seems to have an inherently political or at least socio-political aspect, in addition to the obvious economic "enlightened self-interest" that is also a fundamental part of sympathetic action — noting again that the mere fact that speech is "commercial" or economic does not exclude it from protection under section 2(b). Finally, choosing to act in solidarity with fellow workers can form an integral part of a person's identity and a declaration of their thoughts, opinions, and beliefs. Expression of union solidarity is part of the "embracing marketplace of ideas." The majority's interpretation of freedom of expression in Grain Workers as it relates to sympathetic action is certainly not in keeping with the broad interpretation that freedom of expression has received in other contexts.

As with freedom of conscience, however, the simple fact that sympathetic action may be protected under section 2(b) does not end the inquiry. It must be shown that the freedom has been infringed. For reasons very similar to those raised under freedom of conscience, discussed above, political, see the reasons of Justice Evans. 
it is submitted that the barriers to sympathetic action under statute and common law do infringe upon freedom of expression, that is:

(1) While the "peace obligation" technically affects only expression taken in association, and as such expression stricto sensu does not violate nor is infringed by the peace obligation, the fact that the peace obligation bars the collective exercise of freedom of expression gives the associational aspects of sympathetic action greater value;

(2) Without the possibility of collective action, meaningful freedom of expression in this context is difficult if not impossible;

(3) In jurisdictions where human rights legislation protects freedom of expression, disciplining a worker for undertaking sympathetic action arguably infringes upon that worker's expressive rights; and

(4) Under the common law, Charter values protected by freedom of expression should dictate that the managerial power to discipline workers for undertaking sympathetic action should be lessened or removed entirely, as should the industrial torts. Where the employer is a government actor, retaliation for sympathetic action may contravene the Charter directly.

For these reasons, as with freedom of conscience, I submit that freedom of expression protects a right to sympathetic action, requires a change to the existing law in both union and non-union contexts, and strengthens a claim under freedom of association to limit or remove the prohibition on sympathetic action.

\section{E. FreEdom OF ASSOCIATION AND SYMPATHETIC ACTION}

Association is the "cornerstone of modern labour relations." 180 It is generally recognized that freedom of association is "the most fundamental of all the rights of workers." 181 But its significance is not limited to the workplace; freedom of association serves as a "bellwether" for the status of human rights in general ${ }^{182}$ and its importance has been recognized for many years, perhaps most famously by Alexis de Touqueville: "[ $t]$ he right of association therefore appears to me almost as inalienable in its nature as the right of personal liberty." "183

Historically, freedom of association (and labour) did not fare well before the Supreme Court. In the 1987 Alberta Reference, ${ }^{184}$ the Court interpreted freedom of association in a manner that has been described as "confined," "demoralizing," "minimalist," 185 and perhaps more charitably,

Virginia A Leary, "The Paradox of Workers' Rights as Human Rights" in Lance A Compa \& Stephen F Diamond, eds, Human Rights, Labor Rights, and International Trade (Philadelphia: University of Pennsylvania Press, 1996) 22 at 36.

Alexis de Tocqueville, Democracy in America, translated by Phillips Bradley (New York: Alfred A Knopf, 1945) vol 1 at 196 cited in Gérald-A Beaudoin \& Ed Ratushny, eds, The Canadian Charter of Rights and Freedoms, 2nd ed (Toronto: Carswell, 1989) at 235.

$184 \quad$ Supra note 55.

185 Jamie Cameron, "Due Process, Collective Bargaining, and s. 2(d) of the Charter: A Comment on B.C. Health Services" (2006-2007) 13 CLELJ 233 at 234-35. 
"restrained." 186 Following the Labour Trilogy there were cases that tempered the absolute prohibition on the application of freedom of association to trade union rights. ${ }^{187}$ However, it was not until 2007, with the release of BC Health Services, that freedom of association, the fundamental right most heavily associated with labour, could truly be applied to labour relations. ${ }^{188}$ The Court in BC Health Services did not, however, address the right to strike; ${ }^{189}$ indeed, the Court explicitly refused to rule on that issue. ${ }^{190}$ That had to wait until SFL in 2015, though it is in MPAO that we see the Court's re-formulation of section 2(d) to reflect a new, generous, purposive approach to freedom of association — one focused on encouraging "the individual's self-fulfillment and the collective realization of human goals, consistent with democratic values."

I should repeat, however, that I do not see a necessary connection between a right to strike and a right to sympathetic action. I believe the conscientious and expressive interests within sympathetic action render it distinct enough from the right to strike that it warrants a distinct analysis. However, there is no question that MPAO and SFL have shifted the constitutional debate. The now-invigorated section 2(d) provides firmer support and a more rigourous constitutional analysis for a discussion of sympathetic action, and of collective activity generally.

That said, SFL and MPAO are heavily focused on the guarantee within section 2(d) of a meaningful collective bargaining process. ${ }^{192} \mathrm{~A}$ "meaningful process of collective bargaining" was defined in MPAO as "a process that provides employees with a degree of choice and independence sufficient to enable them to determine their collective interests and meaningfully pursue them." 193 The right to strike is important primarily, though perhaps not exclusively, because it is crucial to the collective bargaining process and to equality therein. ${ }^{194} \mathrm{~A}$ right to sympathetic action, however, is perhaps not necessary in the same way to meaningful collective bargaining. Certainly, historically, sympathetic action and worker solidarity have been profoundly important to workers and their unions. Yet within the current state of the law, it is still not clear that sympathetic action would have the same vital connection to "meaningful collective bargaining" as does the strike. This is especially so because sympathetic action is by definition undertaken in support of other workers' collective bargaining or other persons' interests — not those of the workers undertaking sympathetic action themselves. The reasoning in MPAO and in SFL do not seem to directly lead us to a right to sympathetic action.

Even so, freedom of association, in itself, still can independently protect and promote a right to sympathetic action. In MPAO, the Supreme Court recognized the empowering capacity of

Paul JJ Cavalluzzo, "Freedom of Association - Its Effect Upon Collective Bargaining and Trade Unions" in Ralph Cuervo-Lorens, Peter Dotsikas, \& Allan Maenza, eds, Labour Law Under the Charter: Proceedings of a Conference sponsored by Industrial Relations Centre/School of Industrial Relations and Faculty of Law, Queen's University at Kingston 24-26 September 1987 (Kingston: Queen's Law Journal and Industrial Relations Centre, 1988) 267 at 273. See e.g. Dunmore, supra note 20.

Supra note 9 .

Nor did the Court address the right to strike in a subsequent case dealing with labour rights and freedom of association. See e.g. Ontario (Attorney General) v Fraser, 2011 SCC 20, [2011] 2 SCR 3 at para 190 [Fraser].

BC Health Services, supra note 9 at para 19.

MPAO, supra note 3 at para 46.

Ibid at paras $67 \mathrm{ff}$.

Ibid at para 81.

SFL, supra note 4 at paras 51-55. 
freedom of association and adopted a purposive approach towards the freedom, ${ }^{195}$ echoing Chief Justice Dickson's dissent in the Alberta Reference. Freedom of association may protect the right of individuals to form associations; to collectively promote or involve other constitutional rights; or to give collective voice to the vulnerable and thereby equalize power within society. ${ }^{196}$ Its core purpose is "to protect the individual from 'state-enforced isolation in the pursuit of his or her ends." "197

In addition, section 2(d) is "aimed at reducing social imbalances"198 — an important point that explains the view of association as a "workers' right," given the historical importance of collective action to the advancement of workers' rights, and the recognition by the Supreme Court (most recently in SFL) of workers' vulnerability and the inequality of power within the employer-employee relationship. ${ }^{199}$

Further, a focus on goals or meaningful collective bargaining within the workplace is not a necessary part of a right to sympathetic action grounded in freedom of association. Workers who undertake sympathetic action almost by definition do not have in mind the achievement of goals within their own workplace. To rely overmuch on the goals, however worthy, of sympathetic action leads to an interpretation of freedom of association that is too closely tied to the labour context and leads to a problematic interpretation. Eliminating the distinction between labour and non-labour expression was seen as eminently desirable by the Court in Pepsi-Cola. ${ }^{200}$

As discussed above, the statutory prohibition on sympathetic action only comes into play when collective action is taken. The freedoms of conscience and expression may themselves protect individual workers, but it is association that is the greatest challenge to the statutory definition of a "strike" and to the peace obligation, because the peace obligation does prohibit associational activity qua associational activity.

\section{F. Freedom of Association and the Peace Obligation}

Therefore, freedom of association directly challenges both the statutory definition of a "strike" in Canadian law and the prohibition on mid-term strikes — which when taken together renders collective sympathetic action inherently illegal. As an automatic prohibition, the peace obligation is necessarily an infringement of workers' freedom of association. Further, because the prohibition is statutory, the Charter applies directly. As such, the analysis herein would suggest that the peace obligation should be relaxed or removed to conform to principles of freedom of association.

The same holds true under provincial human rights legislation. Where freedom of association is protected at the provincial level, statutes that violate freedom of association - such as trade union legislation which includes the peace obligation - may be vulnerable to challenge under human rights legislation as well as the Charter. 


\section{G. Freedom OF Association, the LAW OF CONTRACT, AND THE LAW OF TORT}

Association does not present a direct challenge to the law of contract. This is not only because the Charter does not directly apply to the common law; the same would hold true even if considered under provincial legislation. Even if workers exercise sympathetic action collectively, they may run afoul of the peace obligation whether or not they are unionized, but in terms of the common law of contract their "offence" is no greater in terms of refusal of work — they may be disciplined, dismissed, or sued for breach of contract individually.

The Charter values underlying freedom of association, therefore, would seem to have the most impact on the collective industrial torts when considering sympathetic action. The freedoms of conscience and expression would be the freedoms that would more directly shape the common law regarding penalties to individual workers.

\section{SYMPATHETIC ACTION AND SECTION 1: LIMITS JUSTIFIABLE IN A FREE AND DEMOCRATIC SOCIETY}

None of the foregoing freedoms are absolute, a principle expressly recognized in section 1 of the Charter, which "guarantees the rights and freedoms set out in it subject only to such reasonable limits prescribed by law as can be demonstrably justified in a free and democratic society."201

The test to be applied under section 1 was first set out in R. v. Oakes ${ }^{202}$ and has remained essentially unchanged, though it has been refined in subsequent decisions. The Oakes test is a two-step analysis:

First, are the legislative objective or objectives of the legislation pressing and substantial?

Second, does the legislation satisfy the criteria for proportionality? This is a broad question that can be divided into three narrower questions:

(1) Is the impugned law rationally connected to its objective?;

(2) Can the objective of the law be achieved by less restrictive means?; and

(3) Is there an overall proportionality between the objective of the impugned law and its deleterious effects? ${ }^{203}$

\section{A. Pressing and Substantial ObJective}

Canadian labour relations is marked by strict restrictions on the use of the strike and, hence, on sympathetic action. The model has as one of its central concerns the limitation of economic 
harm to third parties to the strike. The Supreme Court recognized this concern as a pressing and substantial objective early in the Charter era. ${ }^{204}$ Chief Justice Dickson in his dissent in Dairy Workers found that the prevention of economic harm to third parties was a pressing and substantial objective under section $1 .{ }^{205}$ Notably, Justice Wilson disagreed on this point, arguing inter alia that economic harm to third parties, in itself, was not necessarily a pressing and substantial concern. ${ }^{206}$ Similarly, in Pepsi-Cola the Court recognized that there would inevitably be some damage to third parties in any labour dispute, but that they should be protected from undue suffering. ${ }^{207}$ In Grain Workers, Justice Evans confirmed that the objective of the peace obligation was to avoid labour disruption and the associated costs and that this was a pressing and substantial objective for the purposes of section $1 .^{208}$

As the very point of sympathetic action is to expand the impact of a strike, the same principles would seem to apply and limiting the unpredictability of sympathetic action as well as limiting the economic harm to third parties are likely pressing and substantial objectives. The analysis must then turn to whether the prohibition on sympathetic action is proportional.

\section{B. Proportionality: RATIONAL CONNECTION}

Similarly, it would seem that the statutory prohibitions on sympathetic action are rationally connected to the objectives identified above. In BC Health Services, the Court noted that it is "not particularly onerous" to establish a rational connection between legislation and that legislation's objective. ${ }^{209}$ The connection does not need to be directly proven; it can be inferred "on the basis of reason or logic." ${ }^{210}$ In both Grain Workers (per Justice Evans) and BCTF, the prohibition on mid-contract strikes was found to be rationally connected to the objective of preventing unpredictable work stoppages and interruption of services. ${ }^{211}$

If the objective of legislation is to limit the impact of strikes, then a bar on sympathetic action would appear to be rationally connected to that objective.

\section{Proportionality: Minimal ImPairment}

In both the pressing and substantial objective inquiry and the rational connection inquiry, the analysis would seem to apply regardless of which freedom is involved. However, when dealing with the minimal impairment and proportionality aspects of the inquiry, the right involved may change the analysis.

While the "freedom not to associate," as described by the Court, appears to have as its core a resistance to "ideological conformity," 212 prohibition on collective sympathetic action is the opposite problem — not forced association, but forbidden association. Indeed, if anything, the

Dolphin Delivery, supra note 23 at 591.

RWDSU v Saskatchewan, [1987] 1 SCR 460 at 476-77 [Dairy Workers].

Ibid at 489, 492-93.

Supra note 136 at paras $44-45$.

Supra note 12 at para 61.

Supra note 9 at para 148 [citations omitted].

RJR-MacDonald Inc v Canada (Attorney General), [1995] 3 SCR 199.

Grain Workers, supra note 12 at para 63; BCTF, supra note 38 at para 55.

$R v$ Advance Cutting \& Coring Ltd, 2001 SCC 70, [2001] 3 SCR 209 at paras 2, 7, 31, Bastarache J, dissenting [Advance Cutting]. See also, ibid at paras 206, 230-32, Lebel J. 
"ideological conformity" that the current state of the law enforces is that of the capitalist state and the "efficiency paradigm." While no right is absolute, neither is the ability of the state to infringe upon it. ${ }^{213}$

At the same time, the prohibition against association leaves individual workers profoundly vulnerable in their individual exercise of conscience and expression. As the Supreme Court has recognized, there is a qualitative difference between individual and collective action. While the peace obligation may only be an infringement of association de jure, it is an infringement of conscience and expression de facto, insofar as it renders the solitary exercise of those freedoms impotent. It is analogous to the Court's recognition in Dunmore that positive action by the State may be necessary where the practical realities render the exercise of a fundamental freedom (in that case, association) unreasonably difficult or impossible.

As the very words "minimal impairment" would suggest, an absolute prohibition on the exercise of a Charter right is likely to fail when lesser measures are available. ${ }^{214}$ Because the law in this case is prohibitive, it is not necessary to consider the imposition of positive obligations such as the duty to bargain in good faith. ${ }^{215}$ It is also notable that, in the case of sympathetic action, unlike the right to strike, it is difficult to see what alternative measures might be used to resolve the dispute. Sympathizers do not have access to arbitration or conciliation, for instance, even if the primary strikers do.

Governments are given a certain amount of discretion to make legislative choices and develop legislative schemes. The courts will not enforce a particular statutory scheme. ${ }^{216}$ Nonetheless there are lesser measures available to governments beyond the blanket prohibition as discussed below. On that basis, I submit that the current statutory prohibition does not minimally impair the freedoms in question and as such must be amended or removed.

\section{PROPORTIONALITY: DETRIMENTAL VS. SALUTARY EFFECTS}

Given the argument that the "peace obligation" fails at the minimal impairment stage, I suggest that any measure of detrimental effects of the peace obligation versus its salutary effects may not be necessary. Nonetheless, I suggest that the detrimental effects - the infringement both de jure and de facto on the freedoms set out in sections 2(a), (b), and (d) of the Charter outweigh the salutary effects of the legislation. absolute ban on advertising during children's programs); SFL QB, supra note 203 (an absolute prohibition on strike action by public servants). 


\section{MOVING FORWARD: SUGGESTIONS FOR REFORM}

\section{A. STATUTORY REFORM \\ 1. The Peace Obligation}

The main reform I suggest is to the Canadian definition of "strike." This serves as the main bar to the traditional exercise of sympathetic action. However, there appear to be a range of legislative choices available that would address the prohibition on sympathetic action without leaving the existing Canadian model topsy-turvy.

\section{a. Removal of Sympathetic Action from "Strike"}

The existing labour relations regime does not require that sympathetic action be contained within the definition of a "strike" or, indeed, that there by any statutory definition of a "strike" at all. British Columbia operated for a number of years with a statute that allowed for protest strikes and sympathetic action while regulating primary strikes. Saskatchewan operated for decades without a statutory definition of "strike." This would be the simplest but perhaps most drastic reform. However, this would only address the associational aspects of sympathetic action, and not necessarily the conscientious or expressive ones for individual workers.

\section{b. Negotiated Exceptions}

Perhaps the approach that would be most in keeping with the underlying premises of Canadian labour relations would be to allow parties who have a collective bargaining relationship to negotiate a clause in their collective agreement permitting workers to refuse to cross a picket line. This is hardly an original concept; many collective agreements already include such a clause.

The late Geoffrey England suggested an innovative approach: clauses in collective agreements that provide that the employer will not schedule work where that would force employees to cross a picket line. ${ }^{217}$ However, this seems an overly technical distinction; if it is possible to negotiate an exemption, unionized workers should be entitled to negotiate a clause that outright exempts them from the "peace obligation."

It is perhaps a great irony of Canadian constitutional law that the fear of the "strike weapon" has led to convoluted decisions to justify constitutionalizing collective bargaining (though this analysis has become significantly less convoluted now that the Labour Trilogy has been well and truly overruled), where loosening strike laws may have prevented the need for such decisions in the first place. In terms of uncertainty and the unintended impact of a strike, the negotiated approach would also allow employers to negotiate clauses where unions would agree not to undertake sympathetic action, or to only do so under certain conditions, such as providing advance notice, or even to provide limited services - along the lines of a negotiated "essential services agreement" — rather than a full refusal. While I argue that sympathetic action is a function of fundamental constitutional freedoms, that does not mean parties cannot negotiate self- 
imposed limits to those freedoms, particularly in a unionized environment where there is greater parity of bargaining power. At the very least, the negotiated approach may breathe some life into the right to sympathetic action. After all, as it stands now, the employer gets that commitment from unions for free, and unions and employers are forbidden from recognizing a right to sympathetic action.

The "negotiated" approach is not without risks. It has been argued, for instance, that bargaining away the right to strike as part of a "neutrality agreement" is unwise and allows for further erosion of workers' freedom of association. ${ }^{218}$ This does not mean that unions could not negotiate away their right to strike or sympathetic action, however, just that they should not. This could be addressed by including the right to sympathetic action as a matter that cannot be bargained to impasse; it is something a union can offer to give up, but not something that can be wrested from them under threat of lockout. This distinction may be a difficult one, as the other issues to be bargained - and which would no doubt form part of the "trade-offs" in negotiating any sympathetic action clause in a contract - could be bargained to impasse. It would not be impossible, however. In Saskatchewan, for example, until recently it was considered an unfair labour practice for an employer to insist upon a collective agreement term of greater than three years, and the Labour Relations Board, in such cases, would be required to determine if that issue had been pressed to impasse. ${ }^{219}$

But, in addition, where some workers may wish to retain their individual conscientious and expressive rights and freedoms to undertake sympathetic action, allowing a union to negotiate a bar to sympathetic action would inevitably conflict with those individual freedoms. Allowing, for example, a majority of workers within a bargaining unit to bargain away the right of bargaining unit members to undertake sympathetic action over the objections of a minority of workers, may not infringe section 2(d) (though there may be arguments that it would amount to enforcing "ideological conformity" as contemplated in Advance Cutting ${ }^{220}$ ) but it may well infringe workers' rights under sections 2(a) and 2(b).

There is no question, therefore, that the "negotiated" approach brings with it certain difficulties and risks.

\section{c. Sympathetic Action as a Form of "Strike"}

A third alternative is to treat sympathetic action as a form of "strike" under labour relations legislation. By this I mean that a union could call for sympathetic action in the same way, and on similar terms, as it could call a strike for its own members (with the necessary exception that the workers could undertake sympathetic action during the term of their own collective agreement). Sympathetic action is already subject to the restrictions on mid-contract strikes and as such is inevitably illegal; there is no corresponding power or immunity under the law as it stands, unlike true strikes. This approach, however, would likely be unworkable and render the "peace obligation" entirely meaningless unless it were tied to supporting an already legal strike.

See e.g. United Steelworkers of America, Local $5917 v$ Wheat City Metals (19 May 2005), 060-05, online: Sask LRB <www.sasklabourrelationsboard.com/pdfdoc/060-05>.

Supra note 212. 
This approach would rob sympathetic action of its immediacy, unless unions were to coordinate ahead of time. If, say, forty-eight hours' notice were required to engage in sympathetic action, that is potentially forty-eight hours where a picket line is up but workers are required to cross. Additionally, many labour relations statutes include other steps that must be taken ${ }^{221}$ such as conciliation, mediation, a "cooling-off" period, and so on, before strike action can be undertaken; though these restrictions could be relaxed for sympathetic action. At the very least, the restrictions and requirements for strike action would need to be relaxed such that a "sympathetic strike vote" could take place during the term of a collective agreement; without a requirement to bargain in good faith (because it is not the workers' own employer who is the target of the sympathetic action); and without a requirement of conciliation or mediation.

Furthermore, and perhaps more fundamentally, were a union to discipline its members for not respecting a call for sympathetic action, a conflict would again arise with individual members' conscientious and expressive rights - without the industrial relations justification that is present in "picket discipline" on a union's own picket line.

While this approach is therefore problematic, it may be a means to balance the interests of workers as well as third parties in a manner that does not offend the Charter.

\section{d. A Modified "Manitoba Model"}

A fourth option - and in my view perhaps the best one - would be to incorporate provisions similar to the Manitoba sympathetic action exemption, discussed below. However, to fully respect Charter freedoms, and particularly freedom of association, certain changes would be required to the Manitoba model. As an exclusively individual protection, this would seem to protect workers' freedom of both conscience and expression. However it does not immunize workers from the peace obligation or penalties for engaging in a "strike." Therefore the provision should be expanded to include an employee or group of employees - a true exemption for meaningful sympathetic action (the fact that the provision does not allow workers to engage in sympathetic action for fellow workers at another branch of the same employer arguably infringe the section 2 freedoms discussed herein as well, and I suggest that restriction be removed). This could, again, be subject to certain conditions to minimize the disruption of sympathetic action.

\section{B. THE COMMON LAW: TORT AND CONTRACT}

I have already argued that the laws of tort (particularly the industrial torts) and contract should be interpreted so as to conform to Charter values, and to provide greater freedom for workers to engage in sympathetic action without fear of discipline. This would entail "reading in" Charter rights in all contracts of employment, and consigning the industrial torts to irrelevance. I will not repeat those arguments here. However, I submit certain statutory amendments would be necessary to fully promote Charter values (and coincidentally in at least three Canadian jurisdictions, conformity with human rights legislation), even with the presumption that workers are entitled to engage in sympathetic action without fear of discipline. 
A jurisprudential presumption that sympathetic action cannot be the subject of retribution by the employer may be sufficient, but statutory protection - whether as part of provincial human rights legislation, employment standards legislation, or labour relations legislation — would provide greater protection and a more reliably Charter-compliant employment law regime. The Manitoba Model is perhaps the simplest possibility, and has the advantage that it already exists in one jurisdiction and need not be invented from whole cloth.

The "contractual" or "negotiated" model presents difficulties in the non-unionized sector. If there were equality of bargaining power within the non-unionized sector, ${ }^{222}$ it would certainly be an option to allow employers to freely negotiate a commitment from their employees not to undertake sympathetic action. However, given the inherent inequality of the bargaining process, this employer power to override a constitutional right seems open to abuse. At the same time, employees often sign contracts that limit their right to exercise their other freedoms; dress codes, for instance, interfere with freedom of expression, but are common in a number of industries. The main concern must be, particularly given the history and value of sympathetic action in the labour context, that employers' superior bargaining power does not render workers' rights illusory. It seems likely that if there is found to be a presumption in favour of sympathetic action at common law, contracts of employment will contain standard clauses rebutting that provision. Unlike in the unionized context, an assurance that this is not a matter that can be required, but only volunteered, to be relinquished, would seem to have little effect in the non-unionized sector.

Another option would be a statutory provision setting out that no contract can include a clause preventing a worker from undertaking sympathetic action, perhaps softened by a proviso that a worker can, in emergency circumstances, be required to perform work that could normally be refused on the basis of sympathetic action - similar to the provisions regarding overtime in some employment standards legislation.

However when viewed in the overall context of the freedoms in question and the power dynamics in the workplace, the Manitoba Model seems the safest choice to protect the rights of non-union workers to engage in sympathetic action. overstated by the courts as well. See e.g. Plourde v Wal-Mart Canada Corp, 2009 SCC 54, [2009] 3 SCR 465, where it was suggested that a UFCW Local in Quebec had bargaining power equivalent to Wal-Mart, one of the largest corporations in the world. 


\section{Conclusion}

Taking all of the above into account, while I submit sympathetic action is a matter worthy of protection under the fundamental freedoms in section 2 of the Charter, there is no easy or absolute answer as to what that means in terms of public policy. Parliament and the Legislatures must have the freedom to craft labour relations regimes that meet the requirements of the times and of their particular jurisdictions. However these concerns are perhaps less urgent or profound than they seem at first blush, as what meets the requirements of the times and of a particular jurisdiction has seemed remarkably uniform across Canada for decades. Nonetheless I submit that two things are clear: an absolute ban on sympathetic action under Canadian labour law violates the Charter and must be removed, and the hostility of the law of tort and the law of contract to sympathetic action is not in keeping with Charter values. Whether through adjudicative interpretation or statutory reform, the law should adapt to reflect these truths. 